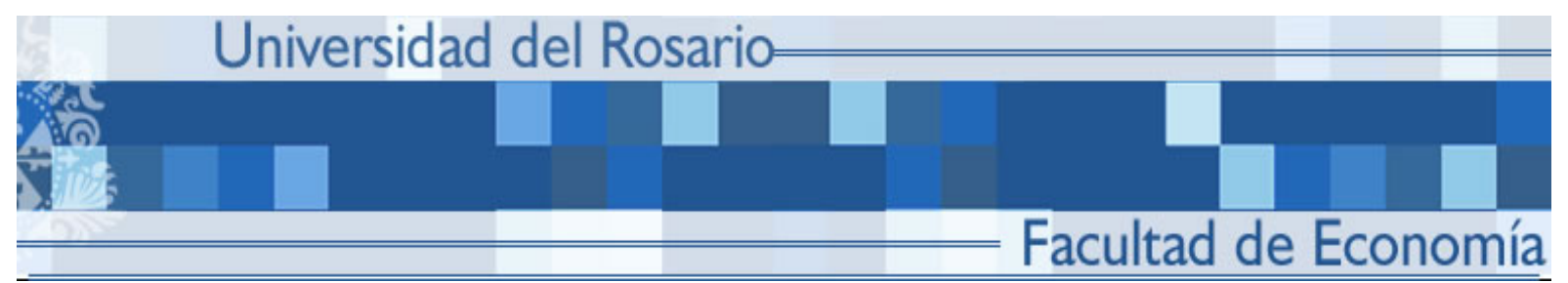

\title{
THE IMPACT OF A PERMANENT INCOME SHOCK ON THE SITUATION OF WOMEN IN THE HOUSEHOLD: THE CASE OF A PENSION REFORM IN ARGENTINA
}

Inés Berniell

Dolores de la Mata

Matilde P. Machado

\section{SERIE DOCUMENTOS DE TRABAJ O}

No. 148

Noviembre de 2013 


\section{The Impact of a Permanent Income Shock on the Situation of Women in the Household:

\author{
the case of a pension reform in Argentina ${ }^{1}$
}

$\begin{array}{ccc}\text { Inés Berniell } & \text { Dolores de la Mata } & \text { Matilde P. Machado } \\ \text { CEMFI } & \text { Universidad del Rosario } & \text { Universidad Carlos III de Madrid } \\ & & \text { and } \text { CEPR }\end{array}$

November 12, 2013

\footnotetext{
${ }^{1}$ Acknowledgments: We acknowledge the support of grant ECO-2010-20504 from Ministerio de Economía y Competitividad Grant (Matilde P. Machado). We thank Manuel Bagüés for valuable insights. We would also to thank Manuel Arellano, Ghazala Azmat, Samuel Bentolila, Julio Cáceres, Guillermo Caruana, Laura Crespo, Juan José Diaz, Francesco Fasani, Libertad González, Mónica Martinez-Bravo, Pedro Mira, Barbara Petrongolo, Diego Puga, Pedro Rey y Luciano Villacorta, for suggestions and comments and the audiences of COSME gender workshop 2013, Universidad del Rosario, Banco de la República (Colombia), Universidad Icesi, Middlesex University, Queen Mary University of London, 7th Annual Meeting of the Impact Evaluation Network, LACEA and Universidad Nacional de Colombia. Carlos Salamanca provided excellent research assistance in the collection of media data for Argentina.
} 


\begin{abstract}
Transfers to women may affect their bargaining power within the household and consequently their well-being. We analyze the effects of the 2004/2005 pension reform in Argentina, that resulted in an unexpected and substantial increase in permanent income for around 1.8 million women, on outcomes arguably related to women's bargaining power within the household. We estimate the effects of the reform in the probability of divorce/separation, the distribution of household chores, and the probability of women being the head of the household, using a Difference-in-Differences approach. Our results show that despite the low divorce probability among seniors, transfers to senior women have substantial effects on their situation in the household. More specifically, we find that the reform had statistically significant effects on the probability of divorce/separation increasing it by $1.8-2.7$ percentage points implying an increase of around $18-19 \%$ on the divorce/separation rate of $60-65$ year old women. Moreover, the probability of being the head of the household also increased by $2.8-3.3$ percentage points representing an increase of $7-19 \%$ in the probability amongst women of $60-65$ years of age. In the case of married women, the probability of being the head of the household increased by $1.3-1.5$ percentage points, which represents an increase of $20-22 \%$. Results show that the distribution of household chores within the couples was also affected by the reform. More precisely, the probability that the wife is the only person in charge of the housework decreased by 5 percentage points, an 11\% decrease. The participation of husbands in housework, however, did not change significantly.
\end{abstract}

Keywords: intra-household bargaining power, marital disruption, divorce, non-contributory pensions, pensions, public transfers, intra-household decision allocation, household chores, collective models, senior women.

JEL Classification: J12, J16, J26, H55 


\section{Introduction}

Over the past two decades, several countries mainly in Latin America introduced social programs to fight poverty and inequality. Amongst the most expensive programs are "non-contributory pensions" which aim to extend pension coverage to individuals who failed to contribute to Social Security (Levy and Schady, 2013). Latin American women are particularly affected by these programs due to their low attachment to the labor market. In this paper, we exploit the non-contributory pension reform that occurred in Argentina in 2004/2005 as a source of a permanent income shock on outcomes arguably related to women's bargaining power within the household. ${ }^{1}$ The unexpected increase in the income of eligible individuals - mostly women - brought about by the reform makes it an ideal setting to analyze exogenous asymmetric income effects within the household. Specifically, we estimate the effects of the reform in the probability of divorce/separation, the probability of women being the head of the household, and the distribution of household chores by differences-in-differences (DD here after) for senior women. Our results show that transfers to senior women have substantial effects on their situation in the household despite their low probability of divorce and perceived stable lives.

The Argentinean pension reform also known as the "moratorium" or "housewives reform" was introduced by two pieces of legislation, Law 25994 art. 6 and Decree 1454/05. Law 25994 was unexpected to the general public perhaps because of the speed with which it went through both chambers: it was discussed and passed in both Senate and Congress in the same day, December 16, 2004. The Decree 1454/05, which extended benefits over time and to other groups, was passed one year later in December 2005. It is not until the mid 2006, however, when the Government regulates the process to access a pension under the two laws. ${ }^{2}$ Comprehensibly, the media coverage of the reform peaks during this period. Data show that the full implementation of the benefits started yet a bit later in the beginning of 2007. The reform allowed individuals who had reached the retirement age but did not fulfill the 30-year social security contribution requirement to retire and benefit from a pension. The objective of the reform was to increase pension coverage in Argentina which was particularly low for women (55\% in 2004) mainly due to their low participation in the labor market

\footnotetext{
${ }^{1}$ There is some discussion about whether the pensions approved by the Argentinean reform should be considered non-contributory. We follow Berniell 2012, Lustig and Pessino 2013, and Levy and Schady 2013 and label them as non-contributory pensions.

${ }^{2}$ BOE 30870, March 21, 2006 and Resolución General Conjunta AFIP 2091/2006, July 2006.
} 
(around $44 \%$ in the 80 s, ILO 2011) and a high proportion of informal jobs. ${ }^{3}$ The percentage of pension beneficiaries among elderly women in Argentina went from 57\% in 2005 to $92 \%$ in 2009 (Benigni et al. 2012). By 2009 the expenditures with the reform represented $2.4 \%$ of the GDP (Lustig and Pessino 2013) and by May 2010 it benefited more than 1,8 million women (D'Elia et al. 2011). This meant a substantial decrease in the probability that women in their mid 60 s had zero income, which in urban areas went from around $35 \%$ before the reform to $10 \%$ after the reform (see Figure 1). In practice, the reform meant that in 2007 an individual who never contributed to social security would be entitled to receive at least $51 \%$ of the minimum pension during the first 5 years - which just exceeds the price of the basket of basic needs for an adult in January 2007 by $2.7 \%$ - and the minimum pension afterward. ${ }^{4}$

Our data comes from the Argentine Continuous Permanent Household Survey (or EPH from the Spanish acronym for Encuesta Permanente de Hogares Continua) for the years $2004-2009$. We restrict our sample to women and estimate the effect of the reform on three sets of outcomes by DD. We use as part of our identification strategy a characteristic of the reform which ascribed all cohorts born before 1945 the right to benefit from a pension by the time they turned 60 without ever having contributed to the social security (SS hereafter). Accordingly, we define as treated all those born between 1941 - 1944 and as control all those born between 1950 - 1953 and compare the evolution of these groups in the pre and post reform periods. All women in the treatment group already turned 60 in the pre-treatment period and are potentially eligible to obtain the maximum benefit of the reform (get a pension without any SS contribution). Women in the control group are younger than 60 during our sample period and are, therefore, not affected by the reform (see details in Section 4).

Importantly, we can neither identify individuals that receive a pension due to the reform nor the number of years of past contributions to the social security. Because of these data restrictions, our estimates identify intention to treat effects rather than treatment effects. We believe, however, that intention to treat effects are also policy relevant parameters since they incorporate endogenous decisions by the population to benefit or not from the reforms. Moreover, were we to observe individual past SS contributions or actual benefit claims, we would need to instrument for these

\footnotetext{
${ }^{3}$ Tornarolli and Conconi 2007 report a $45 \%$ level of informality for all workers but the value for females is likely to be higher (ILO 2011)

${ }^{4}$ The lower pension allowance during the first 5 years is due to the obligation to payback the missing SS contributions which are directly deducted from the pension payments in up to 60 monthly installments. This amount deducted each month during the first 5 years depends on the number of past contributions to the SS.
} 
variables as they would be highly endogenous; a suitable instrument would be hard to find.

A priori, our setting is one where the impact of a pension reform on divorce/separation is likely to be small or close to zero. First, because Argentina is a predominantly catholic country where divorce has only been legal since 1987. Second, because our pension beneficiaries, who are all older than 60, are likely to have been married for a long time. As Becker et al. 1977, and Weiss 1997 show, religion, old age, and marriage duration are factors that decrease the divorce/separation probability. Computation using US data, for example, indicate that the 12-month probability of divorce for women aged $60-65$ is around 0.7 percent. ${ }^{5}$ Unfortunately, there are no such surveys for Argentina, but using data for the city of Buenos Aires we calculate a probability of divorce of 0.73 percent for women aged $60-65 .{ }^{6}$ This probability was probably even lower in the years before the reform due to the large number of 60-year-old women without any source of income (around 39\% in 2004). In that sense, even relatively small transfers such as the ones granted with the pension reform may represent a huge increase in personal income and with it the opportunity to divorce or separate from a spouse or a partner. ${ }^{7}$

Our results show that the pension reform significantly impacted women's income and their situation in the household. First, women's probability of receiving a pension increased by $43-53$ percentage points, which meant a decrease in the probability of having zero income of $27-36$ percentage points and an average increase in income of 61-73 USD PPP 2009. More interesting for our purposes is the even higher income effects obtained in the sample of married women, meaning a $50-55 \%$ increase in the wife's share in the household and the couple's income. ${ }^{8}$ These large income effects were accompanied by an increase in the divorce/separation probability as well as an increase in the outcomes related to the bargaining power within the household: i.e. an increase in the probability of women being the head of the household and a decrease in the wifes' participation in household chores. More concretely, the probability of divorce or separation increases by $1.8-2.7$

\footnotetext{
${ }^{5}$ Authors' calculation using microdata from the 2009 American Community Survey, which provides detailed information regarding changes to the family structure including divorce.

${ }^{6}$ Own calculation based on data on the number of divorces obtained by women $60-65$ years old in Buenos Aires in year 2011 (383) and the number of married women 60 - 64 years old (2010 census data) also in Buenos Aires. We approximate the number of married women between 59-64 years old in Buenos Aires in year 2010 to be roughly $20 \%$ more than the number of married women between 60-64 i.e. 52697. The 12 month divorce probability is obtained as 383/52697. The data was obtained from the Institute of Statistics and the Census of Buenos Aires, years 2010 and 2011.

${ }^{7}$ It is conceivable that an increase in women's income would also lead to some husband-initiated divorces as their alimony payments would be reduced. However, most divorces are filed by women (see footnote 11).

${ }^{8}$ We denote as married both legally married and those living with a partner.
} 
percentage points after the reform which represents an increase in divorce/separation rates of roughly $18-19 \%$ for women between $60-65$ years old. This relatively large impact is likely to reflect a backlog of women who despite wanting a divorce/separation could not afford it. Our large estimates may encompass a short-lived effect comparable to the effects of divorce laws adopted in several countries González and Viitanen 2009. The probability of women being the head of the household increases between $2.8-3.3$ percentage points which represents an increase of around $7-19 \%$ for women between $60-65$ years old. Since this large effect may simply be a consequence of an increase in the number of divorcees/separated in our treatment group, we re-estimate our model using the subsample of married women. In the case of married women, the probability of being the head of the household increases by $1.3-1.5$ percentage points, which represents an increase of $20.3-22.0 \%$. Finally, the probability that the wife is the only person in charge of the housework decreased by 5 percentage points, a $11 \%$ decrease, while the participation of husbands in housework and the provision of domestic services by non-household members do not change significantly. Our results for the married women sample can be interpreted more generally as IV estimates of the effect of the female's income share within the couple on the probability of being the head of household and distribution of household chores. The IV estimates are obtained as the ratio between the DD coefficient of the outcome and the DD coefficient of the share of income regression. They imply that a 10 percentage points increase in female's income share within the couple leads to an increase of the probability of being the head of household of about $1.3-1.4 \%$ percentage points or $18-20 \%$ and a decreasing in women's sole participation in household chores of $4.8-4.9$ percentage points or roughly $11 \%$.

We extend our model in two ways. First, we allow the reform to have different effects by educational levels. We find an interesting pattern: although the average income effect is lower for women with high education as less of them claimed benefits from the moratorium, they tended to opt-out of their marriages by increasing their probability of divorce/separation; on the contrary, the low-educated women opted-in and gained more bargaining power within their marriages. Second, we present an analysis of the very short run effects (maximum 15 months after the reform) of the reform exploiting the panel dimension of the EPH survey. The results indicate that divorce probabilities and bargaining power do not change over such a short horizon. There are several possible explanations for why we do not observe effects in the very short run. First, the income effect in less than 15 months after the reform is much lower than over a larger horizon. Citizens, particularly 
seniors, may have difficulty accessing benefits even though they are entitled to them. Second, it is possible that women need to accumulate a certain amount of income before they can separate from their partners. Third, it is likely that women try to bargain a better position before deciding on divorce/separation. Nonetheless, when restricting the sample to married women, we do not observe any short-run effects on the bargaining power of women in the household either. Fourth, when using the panel, we loose a substantial number of observations. Fifth, attrition related to the treatment is likely to be responsible for the lack of divorce/separation variability in the panel. The idea is that divorcees/separated women who leave the house are most likely dropped from the sample, which would automatically lead to a lack of variation in divorce.

Finally, we present robustness checks based on placebo treatments that show that our results are not driven by systematic differences between the control and the treatment group other than the different evolution in their income due to the reform.

This paper contributes to two very extensive literatures. On the one hand, the literature on decision and allocation within the household and on the other hand, the literature on the determinants of divorce/separation. The literature on decision and allocation within the household, initiated with the work of Becker (Becker 1974), has evolved dramatically to establish that most economic decisions taken within the household depend on incomes (earned and unearned), prices, opportunity costs and preferences of both partners and are, therefore, inconsistent with the traditional "unitary" view of a unique utility maximization entity with income pooling (Manser and Brown 1980, McElroy and Horney 1981, McElroy 1990, Thomas 1990, Schultz 1990, Lundberg and Pollak 1993, Bourguignon et al. 1993, Lundberg and Pollak 1996, Lundberg et al. 1997, Gray 1998, Browning and Chiappori 1998, Chiappori 1988, Browning et al. 2011, among others). ${ }^{9}$ Models of allocation within the household and the accompanying empirical evidence, in general, predict an increase in outcomes and demands preferred by women following an unexpected increase in women's income share in the household, such as the one brought about by the Argentinean pension reform. To the extent that a more equal distribution of household chores and being the head of the household proxy for greater well-being in the household, our results conform with this literature. ${ }^{10}$

\footnotetext{
${ }^{9}$ Browning et al. 2006 clarify the definitions of unitary and non-unitary models. In particular, they show that "income pooling" is not specific to "unitary" models. Hence, using their model classification, the evidence of a sharing rule that depends on distribution factors as in Bonke and Browning 2009 is consistent with either a "collective" model or with a "distribution factor dependent unitary" model.

${ }^{10}$ Sociologists studying the relationship between household work and earnings find, in general, a negative correlation
} 
The household decision and allocation literature, however, does not provide a prediction about the impact of income shocks on divorce/separation. Bargaining models with within family noncooperative threat points (Lundberg and Pollak 1993 and Lundberg and Pollak 1996), for example, depict family settings where divorce is too costly or impossible. Other bargaining models of marriage (McElroy and Horney 1981), however, incorporate divorce/separation as a threat point into the Nash bargaining problem. An increase in the utility in case of divorce/separation leads to a better outcome from the Nash bargaining. Despite not being conditional on divorce, the increase in income brought about by the Argentinean pension reform undoubtedly improves threat points, specially for women, and should increase women's happiness with their marriage according to these models.

The beginnings of the divorce literature (Becker 1974, Ross et al. 1975) predicted an increase in the probability of divorce over time as the benefits from marriage, e.g. gender specialization, decreased. In particular, the "independence effect" hypothesis (Ross et al. 1975) predicted a decrease in the gains from marriage and, therefore, an increase in divorce/separation rates with the increase in married women's income relative to their husbands. ${ }^{11}$ This theory, which gained empirical support with the co-movement of female labor force participation and divorce rates in the United States from 1960 until the end of the 70's, triggered a number of empirical studies particularly within the sociology literature (e.g. Sayer and Bianchi, 2000). One hindering difficulty in this literature, which motivated the work of several economists, is to estimate income effects stemming from truly exogenous shocks. Within the economics literature, the weight of the evidence is in favor of the "independence effect" hypothesis (e.g. Becker et al. 1977, Weiss and Willis 1997, Weiss 1997, Jalovaara 2003, Bobonis 2011, Doiron and Mendolia 2011) although there are noticeable exceptions (Hoffman and Duncan 1995 and more recently Hankins and Hoekstra 2011) ${ }^{12,13}$. Our results not only concur with the "independence effect" hypothesis but show that these effects are still present in old age.

between women's earnings and household work (see for example Bittman et al. 2003 and the references there in). Interestingly, this pattern reverses when women start to earn more than their husbands in an effort to maintain their gender identity (Bittman et al. 2003 and more recently Bertrand et al. 2013). See Biddlecom and Kramarow 1998 for a suggestive relationship between headship and variables related to attitudes and economic power of women.

${ }^{11}$ Note that most divorces are filed by women (Brinig and Allen 2000; Friedman and Percival 1976).

${ }^{12}$ When divorce/separation is either illegal or not socially accepted, theory predicts an increase in conflicts following an income shock. Anderson and Genicot 2012, for example, find an increase in male and female suicidal rates in India due to better property rights for women. In a purely theoretical framework, Anderberg and Rainer 2011 also predicts a inverted u-shape relation between female's income and domestic violence when divorce/separation is not an option.

${ }^{13}$ Note that the literature on the determinants of divorce and union dissolution more generally is too extensive to be discussed here. In particular we leave out of the discussion those papers that study policies or transfers that affect the benefits or costs conditional on divorce since the transfers brought about with the Argentinean pension reform were not conditional on marital status. 
Another literature also related to our paper is the one that analyzes the effects of pension transfers (Duflo 2000, Bertrand et al. 2003, Edmonds 2006, Posel et al. 2006, Sienaert 2008, Ardington et al. 2009, Ponczek 2011, de Carvalho Filho 2012, Bosch and Guajardo 2012, Danzer 2013). It concludes that pension transfers affect the labor supply of recipients and non-recipient household members, and also improves children outcomes, such as nutrition status and school attendance. The latter effect is observed especially when the pension recipient is female. To the extent that an improvement in children outcomes reveals a higher bargaining power of women within the household, the evidence provided by these papers is very related to our objective.

The rest of the paper is organized as follows. Section 2 describes the pension reform in Argentina. Section 3 describes the data set. Section 4 describes the empirical strategy. Section 5 describes the main results. Section 6 shows the results of placebo treatments, and in Section 7 we allow for heterogeneous effects by education and exploit the panel data dimension of the survey to estimate very short-run effects. Section 8 concludes. Section 8.1 contains tables and figures.

\section{The Pension Reform}

In Argentina, women may retire at 60 and men at 65 . Besides reaching the retirement age, a worker must have 30 years of Social Security (hereafter SS) contributions to be entitled to collect a pension. These requisites together with a traditionally low female participation in the labor market (around $44 \%$ in the 80s, ILO 2011) and an increasingly high level of informal jobs (45\%, Tornarolli and Conconi 2007), resulted in a low pension coverage, especially amongst women; by 2004, only 55\% of age-eligible women received a pension, and only $35 \%$ if widows are excluded (Figure 2). Pension coverage was higher for males $(75 \%)$ due to their higher labor force participation.

In December 2004, the Argentinean Government approved a reform to the pension system (Law 25994), which allowed people who had reached the retirement age, i.e. cohorts 1944 and older, but did not fulfill the 30-year SS contribution requirement, to get a pension and health insurance coverage. The reform was implemented through a payment schedule, which was officially named "moratorium" and popularly known as "the housewife's pension" because housewives were perceived as the group of the population that benefited the most. The payment schedule consisted of paying back to the SS 
the amount corresponding to the number of years (up to 30) the individual had failed to contribute. The debt to the SS would be paid in up to 60 monthly installments and was deducted directly from the individual's monthly pension benefit. The law also established a maximum deduction of $49 \%$ (Lustig and Pessino, 2013). Hence, the lowest benefit, which was received by those that had never contributed to the system, e.g. housewives, corresponded to $51 \%$ of the minimum pension during the first 5 years, i.e. 304 ARS in 2007 or 191 U.S. dollars PPP 2009 per month, and 596 ARS or 374 U.S. dollars PPP 2009 per month afterward. The basket of basic needs for an adult in Argentina in January 2007 cost 295.89 ARS (Source: INDEC). Importantly, benefits were not automatic and those eligible had to apply in order to benefit from a pension. Information from unofficial blogs suggest that the procedures were not straightforward.

Law 25994 expired in April 2007 but this expiration had no effects on the 1944 or older cohorts with the approval of Decree 1454/05 in December 2005. In addition, the approval of the Decree allowed younger cohorts to also benefit from the moratorium although it established harsher conditions of access. Hence, the pension reform affected different cohorts differently: older cohorts - born in 1944 or earlier - benefited relatively more than younger cohorts. ${ }^{14}$ In our empirical exercise, we are going to focus on the effects of the reform on those cohorts that benefited the most i.e. cohorts born before 1944 .

In Argentina, a law proposal must be discussed and approved in the Senate and the Congress before it becomes a law. Law 25994 was unusual in the sense that it was discussed and approved in both Congress and Senate on the same day, December 16, 2004. Moreover, its antecedent, Bill 1183-D-03 of April 2003, did not refer to any benefits to the 1944 or younger cohorts. We believe that this unusual trajectory may have contributed to the scarce media coverage received before December 2004. Despite the unusual fast approval process, the pension reform took approximately 2 years to be fully implemented. One reason was the delay in regulating the process to access a pension under the moratorium, which was complete in July 2006 (BOE 30870, March 21, 2006 and Resolución General Conjunta AFIP 2091/2006, July 2006). Comprehensibly, the media coverage of the reform peaks during this period: as we show in Figure 3, news related to the reform from the two major newspapers in Argentina, La Nacion and El Clarin, are concentrated in the last months of 2006. Concerns that news may be strategic or biased in favor or against the Government are dissipated

\footnotetext{
${ }^{14}$ Decree $1454 / 05$ extends the moratorium only to the self-employed. We could not find evidence on whether this requirement was effectively monitored or binding in practice.
} 
by observing a similar timing pattern from google search counts, for example (see Figure 4). Social Security expenditures with the moratorium, as D'Elia et al. 2011 suggest, take off only in 2007. The number of pension recipients and the income effects observed in our data are consistent with that implementation date (see Figure 2).

\section{Data}

We use the Argentine Continuous Permanent Household Survey (Encuesta Permanente de Hogares Continua, EPH from hereafter) for the years 2004-2009. The EPH is a rotating panel quarterly survey. Each household is in the panel in 4 quarters corresponding to two alternating periods of two quarters each spanning one year and a half: surveyed for two consecutive quarters in the first year, out of the sample for the next two quarters, and surveyed again in the following two quarters. Each quarter, there are approximately 25,000 households surveyed. The rotating panel is designed in such a way that in each quarter $25 \%$ of the panel is replaced by households that are interviewed for the first time. The survey covers 32 urban regions representing $62 \%$ of the country's population although in our analysis we restrict to 29 urban areas since three of them were incorporated in the EPH only in 2006. The survey includes one household questionnaire and individual questionnaires for every person in the household. These questionnaires contain questions about housing conditions, household and individual incomes, demographic characteristics, occupation and working conditions, certain types of social benefits, etc. Unfortunately, however, there is neither information on the number of years each individual contributed to the SS - which would have allowed us to identify which individuals were more or less affected by the policy - nor it is possible to identify those individuals who claimed benefits from the moratorium.

In our empirical analysis below we start by measuring the effect of the reform on different measures of personal income. Concretely, we consider the following income measures: the probability of receiving a pension ${ }^{15}$, the probability of not having any personal income, the amount of monthly personal income, and for legally married women or those leaving with a partner also the wife's share of income within the household and within the couple. ${ }^{16}$ Because monthly income is sometimes

\footnotetext{
${ }^{15}$ We constructed a dummy variable for "receives a pension" from the "income from pensions" category. Only $2 \%$ of pension incomes were imputed by the Statistical Office.

${ }^{16}$ We consider that a woman is receiving a pension whenever she reports "pensions" as a source of her personal
} 
left unreported, the Statistical Office created a twin variable where missing values were imputed. We transform Argentinean currency (Pesos ARS) to U.S. dollars (USD) using the purchasing power parity (PPP) conversion factor for private consumption. ${ }^{17}$ This number represents the units of ARS required to buy the same amounts of goods and services in the domestic market as 1 USD would buy in the United States. We also use the U.S. annual inflation rate to adjust for price changes in the United States throughout our period of analysis. Therefore, 1 U.S. dollar (PPP 2009) has the same purchasing power as 1 USD had in the United States in 2009.

Once we establish that the reform had a significant impact on women's personal income and income shares, we are interested in its effects on: the marital status of women, in particular the probability of divorce/separation; ${ }^{18}$ the identity of the household head; and the housework sharing within the household. The information used to construct the variables related to the identity of the household head and housework sharing comes from the household module of the survey where, unfortunately, the respondent is not identified. The respondent to the household module identifies the household head according to her own judgment since the definition provided by the Statistical Office, in charge of the EPH, provides little guidance - "household head is the one who is recognized by the household members as such." Being the household head is, therefore, compatible with being the main breadwinner as well as with being the main decision maker or both. The respondent to the household module also identifies which household members contribute to household duties — whether they do most of the housework or just help-, as well as whether the household has domestic service or receives some external help. ${ }^{19}$ We construct the following variables: i) A dummy variable that takes the value one if the wife is the only responsible for most of the housework activities in the household i.e. no other household member is identified as in charge of most of the household chores; ii) a dummy variable that takes the value one if the husband is responsible for most of the housework - whether or not he is the only one responsible ${ }^{20}$ iii) a dummy variable that takes the value one if the husband contributes to housework activities - he is either responsible for most of the housework

\footnotetext{
income in the individual questionnaire.

${ }^{17}$ The PPP conversion factor is published by the International Comparison Program database (World Bank).

${ }^{18}$ The survey question does not allow us to distinguish between divorced and separated.

${ }^{19}$ Specifically, we use the closed-form answers to the following questions on the household questionnaire: 1 ) "Who does most of the housework?". Respondents can indicate up to two household members, domestic service or other help from people who do not live in the household; 2) "What other people help in the household chores?" where respondents indicate which other household members help with these chores, or whether they receive external help or have domestic service.

${ }^{20}$ We do not construct a variable similar to i) for husbands since there are very few observations where husbands are identified as the only responsible for most of the housework.
} 
or just provides some help, iv) a dummy variable that takes the value one if the household has domestic service or external help with housework activities.

Other individual characteristics that we include as control variables in our regressions are region of residence (dummies for urban areas where the EPH is conducted), educational level - high and low dummies, where low education indicates less than high school diploma-, and a dummy variable to identify those who were born abroad. Additionally, for married women, we construct variables to reflect age and educational differences between spouses. The latter is constructed taking differences between the spouses' level of education attained, with a positive value when the wife is more educated than the husband. ${ }^{21}$

Our sample includes women born between 1941 - 1944 and 1950 - 1953 (see Section 4 for the details about the sample selection). ${ }^{22}$ Our baseline analysis uses the EPH as repeated cross sections. The final database contains 46,047 individual observations of women aged between 51 and 68 years old. In the pre-reform period, $13 \%$ of these women were divorced or separated, $8 \%$ were single, $15 \%$ were widows, and the rest were married or living with a partner. At that time, $35 \%$ of the women were the head of their households, and $38 \%$ did not receive any personal income. In the subsample of married women, only $7 \%$ were the head of the household, on average their personal income represented $20 \%$ of the total household income, and $40 \%$ of them were the only responsible for doing the household chores. $11 \%$ of the husbands were responsible for housework and $26 \%$ helped with housework. Only $4 \%$ of the sample had domestic service or external help.

\section{Empirical strategy: Difference-in-Difference Estimation}

Although the Argentinean pension reform law was passed in 2004/2005, its full implementation started in 2007 as argued in Section 2 and shown in Figure 2. Since our data set covers the period $2004-2009$ we may compare outcomes of treated individuals before and after the law came into

\footnotetext{
${ }^{21}$ The maximum level of education attained is a categorical variable available in the EPH. We assign values between 0 to 6 to each category. The maximum education category is "Higher Education (complete)" with the value 6 , and the minimum is "no formal education" with the value 0 . The other categories are "elementary school (incomplete)", "elementary school (complete)", "High School (incomplete)", "High School (complete)" and "Higher education (incomplete)".

${ }^{22}$ Data for the third quarter of 2007 is not available because some regions could not be surveyed due to administrative problems in the Statistical Office.
} 
effect as part of our identification strategy. Accordingly, we define the period 2004-2006 as the pre-treatment period and the period $2007-2009$ as the post-treatment period. ${ }^{23}$

To complete our identification strategy, we exploit a feature of the reform that granted differential treatment to different cohorts. This discontinuity in treatment allows us to identify a treatment and a control group. We are going to focus on those cohorts that benefited the most from the reform, i.e. those born before 1944, as explained in Section 2. Accordingly, we define as treated all women born between 1941 and 1944 for two reasons: On the one hand, all these women already turned 60 by 2004 - their ages range between 60 and 65 in the pre-treatment period and between 63 and 68 in the post treatment period ${ }^{24}$, which allows us to isolate the effect of the reform from the effect of changes in individual labor market decisions that occur at retirement age. On the other hand, in 2007 - the year the reform is fully implemented - all women in the treatment group are potentially eligible to obtain the maximum benefit (i.e., may include up to 30 years in the payment schedule as shown in Table 1). Note that since we neither observe the number of years individuals contributed to the SS system nor who actually claim benefits from the moratorium, our estimates identify intention to treat (ITT) effects. Our control group is composed by women born between 1950 and 1953 who are, by definition, never affected by the reform during our sample period since their ages range between $51-56$ in the pre-treatment period and between $54-59$ in the post treatment period. Table 2 summarizes the cohort and age composition of the treatment and control groups. Using administrative records, D'Elia et al. (2011)'s Figure 4.4., show that by May 2010 there were roughly 506,000 women between 65-69 years old-i.e. of the same cohorts as our treatment group - affected by the moratorium.

Figures 6 and 7 show that after the reform the percentage of women in the treatment group who receive a pension increased from aproximately $30 \%$ to more than $75 \%$ and that, as a result, the percentage of women without any personal income fell from roughly $40 \%$ to $12 \%$. Figures 6 and 7

\footnotetext{
${ }^{23}$ We do not consider the years before 2004 since the EPH suffered important methodological changes in 2003. Neither do we include data after 2009 to insure women in the control group do not turn 60 and become treated (see Figure 5 for the evolution of retirement rates across time for each cohort between 1941 - 1953). Another important reason to leave years after 2009 out of the sample is the announcement and implementation of the Universal Child Allowance program (Asignación Universal por Hijo para Protección Social) at the end of 2009. This program paid a monthly amount per child under 18 to parents working in the informal sector or unemployed (Resolution ANSES № 393/2009). By 2011 almost $95 \%$ of the beneficiaries were women (ANSES, 2012).

${ }^{24}$ To be precise, the EPH does not include information on "year of birth" and only includes information on "age". This implies that a proportion, hopefully small, of individuals are misclassified. An example would be a woman who declares to be 60 years old in January 2005 but turns 61 in February 2005. This woman would not be classified as treated (nor as control for that matter) although she was born in February 1944.
} 
also show that: 1) the increase in pension coverage and personal income of women in the treated cohorts were effective in $2007 ; 2)$ women from the control group were unaffected by the reform.

Table 4 shows the pre and post-treatment means of a set of relevant variables for the treated and control groups. Differences between the treated and control groups are mostly due to their age difference. For example, the treatment group has more widows - and therefore more heads of household and more pension beneficiaries. In addition, because the younger cohorts are typically more educated, there are also noticeable differences in education.

The difference-in-differences strategy relies on the assumption that the evolution of the outcome of the treatment group in the absence of the reform would have been the same as that of the control group, conditional on observed characteristics. We check the plausibility of this assumption by comparing the evolution of the outcomes of interest for the treated and control groups during the pre-treatment period. Specifically, we plot the estimated quarter-year coefficients of the regression of outcomes on quarter-year dummies, estimated separately for treatment and control cohorts. Naturally, because these are different cohorts and our sample consist of repeated cross sections it is important to control for the same exogenous characteristics that we use in our main specification (equation 1). Figures 11 to 15 show the estimated values of the quarter-year dummies. The time trends of treatment and control groups for all our outcomes are very similar before the reform took effect in $2007 .^{25}$

In summary, our empirical strategy is a standard difference-in-difference where we compare the evolution of outcomes of the treatment group across time with the evolution of outcomes for the control group. Let $Y_{i t}$ be the outcome of interest for individual $i$ in time $t$. Our model specification is

$$
y_{i t}=\alpha+\beta \text { Treat }_{i} \times \text { Post }_{t}+\delta_{i}^{C}+\delta_{t}+X_{i}^{\prime} \gamma+\varepsilon_{i, t}
$$

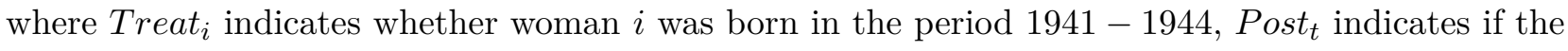
outcome is observed in the post treatment period $2007-2009, \delta_{i}^{C}$ and $\delta_{t}$ are cohort and period (yearquarter) fixed effects, $X_{i}$ is a vector of individual characteristics (i.e. a dummy variable of high level

\footnotetext{
${ }^{25}$ In the case of divorce/separation in Figure 11 there are two post-treatment quarters where the estimated period effect for the control group spikes downwards. We re-estimated the divorce/separation DD model dropping those two quarters of data and our results do not change significantly.
} 
of education, a dummy variable that equals one if the individual was born abroad and 28 dummies for region of residence) and $\varepsilon_{i t}$ is a residual. The coefficient $\beta$ represents the difference-in-difference estimate of the effect of the reform.

The baseline results presented in the next Section do not make use of the panel structure of the data. This implies that observations from the same individual are treated as independent. Appropriate clustering of the standard errors could account for some of the correlation between error terms belonging to the same individual. For example, if we would apply two-way clustering at the cohort and year-quarter levels we would account for correlation among observations of the same cohort - whether or not they are observed in the same year-quarter- as well as for correlation among observations in the same quarter — whether or not they belong to the same cohort. However, because the number of clusters for the two-way clustering would be small -8 cohorts and 23 yearquarter periods - we decided to use one-way clustering at the cohort-year-quarter level; the two way cluster estimator needs a large number of observations in both the cross section and time series, Cameron et al. 2011 and Villacorta 2013. This effectively only accounts for correlation among the same cohort when observed in the same year-quarter and not for correlation belonging to the same individual. In Section 7.2 we specifically use the panel structure and account for individual fixed effects although at the expense of observing the effects of the reform only in the very short-run, accounting for a much lower number of individuals, and potentially incurring a problem of attrition.

An important concern in our setting is related to potential anticipation effects amongst women in the control group as they perceive themselves as future beneficiaries of the moratorium. Such anticipation effects, however, would bias downward our difference-in-difference estimates, reinforcing our results.

\section{Results}

\subsection{Effects of the reform on women's income}

In this Section we show difference-in-difference (DD hereafter) estimates of the effect of the reform on women's probability of receiving a pension, on the probability of having no personal income, and 
on their monthly personal income using equation 1's specification. ${ }^{26}$ In columns $1,2,5,6,9$ and 10 of Table 5, we report results for the sample of all women regardless of their marital status whereas in columns $3,4,7,8,11$ and 12 we present estimates when the sample is restricted to married and divorced/separated women (i.e., excluding singles and widows). Results for the sample of married women are shown separately in Table 6 .

Results presented in Table 5 indicate that the implementation of the pension reform was very successful in increasing the percentage of women receiving a pension, between $43-44$ percentage points (pp) for the whole sample (145\%) and between $53-54 \mathrm{pp}$ once widows and singles are excluded (313\%). For senior Argentinean women, receiving a pension meant a reduction of $27 \mathrm{pp}$ on the probability of having no personal income $(67 \%)$ or 36 pp once widows and singles are excluded $(70 \%)$ (columns $5-8$ in Table 5). Columns 1 and 2 of Table 6 show that married women benefited the most from the reform with a $54.4 \mathrm{pp}$ increase in the probability of receiving a pension (340\%), 39 pp decrease in the probability of having no personal income (68\%) and 71.14 USD (PPP 2009) increase in personal income $(36 \%) \cdot{ }^{27}$

Columns $9-12$ in Table 5 show the estimates of the impact of the reform on women's monthly personal income. The estimated effect is between $61-73$ USD (PPP 2009), and a similar result is shown in columns 3 and 4 of Table 6 for the group of married women. Note that since these are intention to treat effects - i.e. not all women in the treatment group were effectively treated - the real income effect on the treated is much higher than the ones presented in this table. Nevertheless, results shown in the last four columns of Table 6 indicate that the reform had a significant positive and large impact on a wife's contribution to the couple's and the household income which increased by $10-11$ pp or $50-55 \%$.

\footnotetext{
${ }^{26}$ All linear probability models presented in Sections 5, 6 and 7 yield similar results to those obtained using probit estimations. For the sake of brevity, results from probit estimations are not shown here, but available upon request.

${ }^{27}$ Although the reform decreased labor force participation around $8 \mathrm{pp}$ (see Table 9), most of the effects on income come from the impact on women who did not have any income sources. Our results on labor force participation are in line with those of Bosch and Guajardo (2012) although our effects are larger (the reduction of women labor force participation is about $4 \mathrm{pp}$ in their paper) due to differences in the definitions of treatment and control groups.
} 


\subsection{Effects of the reform on the probability of divorce/separation}

Table 7 reports DD estimates of the effect of the reform on the probability of being divorced or separated. Results show that the implementation of the reform had a positive and significant impact on the probability of divorce and separation, increasing it between $1.8-2.7 \mathrm{pp}$. These effects are large if we take into account that the share of women in the treatment group who were divorced/separated before the reform was only $10 \%$ and that the probability of divorce at these ages is low. Data for the US shows that the 12-month probability of divorce for women $60-65$ is around $0.7 \%$ in 2009 and this figure is surprisingly similar to the figure obtained for the city of Buenos Aires for the same ages in $2011(0.73 \%$, see footnote 6$)$. However, we believe that in Argentina divorces are less common than separations since divorces are lenghty and complicated processes. ${ }^{28}$

A fair criticism to our analysis would be that our results are potentially affected by compositional effects originated from a different evolution of the proportion of widows in the treated and control groups. For example, women that are married in the pre-treatment but become widows in the posttreatment do not remain in the sample of divorce and married women (" $\mathrm{d}+\mathrm{m}$ " in the tables) in the post-treatment period. Hence, a higher probability of widowhood amongst the treated automatically generates a larger increase in the rate of divorce/separation $(d / d+m)$ for the treatment group because the number of married women in the denominator decreases. Similarly, a higher probability of marriage among singles in cohorts similar to the control group's would lead to an increase in the post-treatment denominator for this group and an upward bias in our estimated impact on divorce/separations. We follow three approaches to check that these compositional effects cannot explain our results: 1) we show that excluding widows and singles from the sample does not alter qualitatively our results; 2) we estimate equation 1 but using as an outcome variable an indicator for being a widow; 3) we estimate equation 1 but using as an outcome variable an indicator for being single. Results of the latter two exercises show that the estimated DD parameter is zero, which indicates that the results presented in Table 7 are not driven by differences in the evolution of widowhood or spinsterhood among treated and control groups (results not shown here, but available upon request).

\footnotetext{
${ }^{28}$ Some of the features of divorce law in Argentina are: First, there is no unilateral divorce; Second, couples need to be separated for 2 years before they can file for a divorce; Third, if a woman files for divorce and she has no income source, it is up to the judge to decide how much and for how long her ex-husband should grant her alimony. Moreover, in the latter situation if the ex-husband were the first to die, his ex-wife could not inherit from him and would be left without any income source.
} 
An additional source of compositional effects is the one that occurs through mortality. Mortality rates increase with age and, therefore, should be higher in our treatment group than in our control group. However, mortality would only bias our results upwards if it would occur more than proportionately amongst married women (versus divorced women). Research shows that this is however not the case (Manzoli et al. 2007).

\subsection{Effects of the reform on the bargaining power of women}

DD results in Table 7 show that after the pension reform, the probability of women being the head of the household increased significantly. The estimated effect ranges from $2.8 \mathrm{pp}$ to $3.3 \mathrm{pp}$, implying a 7.3-8.7 percent increase. For the married women sample (Table 8), the estimated effect of the reform on the probability of women being the head of the household is $1.3 \mathrm{pp}$, although statistically significant only at the 10 percent level; a result which is consistent with an increase in the bargaining power of wives within the household. The results reported in column 2 of Table 8 come from a regression that includes in addition to women's education and regional fixed effects, an indicator of being born abroad, and the age and educational differences within couples. The latter two variables are commonly used in the literature as distribution factors (Browning et al. 2011) and proxy for women's bargaining power previous to the reform. Their inclusion does not affect the estimated effects substantially but slightly reinforces our results by making them larger and more precisely estimated.

To further analyze the gains in married women's bargaining power, we estimate the impact of the pension reform on outcomes related to the division of housework within the household. Given that women are traditionally the ones in charge of housework, an increase in women's bargaining power within the household is likely to affect these outcomes. ${ }^{29}$ Although, there is some effect for the sample of married and separated women, the effect is more pronounced and statistically significant for the sample of married women. Concretely, in columns 3 and 4 of Table 8 we show that the reform reduced significantly by 5 pp the probability that the wife is the only responsible for household chores. This result, however, would not reflect changes in bargaining power if it were entirely driven by a

\footnotetext{
${ }^{29}$ In Lundberg and Pollak (1993) "separate spheres" bargaining model, divorce is not an option. Therefore, when bargaining fails, there is a non-cooperative equilibrium with an under-provision of the public good that each member of the couple provides according to gender specialization (the supply of household services in the case of women).
} 
pure income effect associated with the reform that allowed women to substitute their own time for paid domestic services. In columns 5 and 6 we discard this possibility by showing that the reform has no significant effect on the probability of having domestic service or other kind of external help. The remaining columns in Table 8 show that the reduction in women's responsibility for housework occurs simultaneously with an increase of $2.4-2.5 \mathrm{pp}$ (columns 7 and 8 ) in the probability that the husband does some housework and an increase of $1.4-1.6 \mathrm{pp}$ (columns 9 and 10) in the probability that the husband does most of housework, although none of these increases is statistically significant. ${ }^{30}$ Taken together, the results from Table 8 reflect that gender roles in the household become more alike with the reform. Moreover, since the reform occurs simultaneously with a (small) reduction in women's labor force participation ${ }^{31}$ and, hence, an increase in women's available time to dedicate to household activities, we argue that our estimates of columns (1)-(4) of Table 8 are likely biased downwards. In which case our conclusion about the reform bringing an increase in the bargaining power of women - allowing them to be less involved in housework activities - is reinforced.

\section{Placebos}

One concern with our methodology is that different age profiles in the treatment and control groups may blur the identification of the treatment effect. While effective in controlling for age differences within treatment and control groups, the cohort and year dummies included in all the estimations so far, are ineffective across groups because their age profiles do not overlap. Hence, to discard that results obtained in Section 5 (Tables 7 and 8) are attributed to the different outcome trends associated with the different age profiles across groups, we estimate a placebo treatment effect using data from pre-treament years. The idea is to show that age differences across groups have zero impact on DD estimates. ${ }^{32}$

Specifically, as in our original framework we include 6 years in our analysis $(1996-2001)$, and define the period 1996 - 1998 as the placebo pre-treatment period, and 1999 - 2001 as the placebo

\footnotetext{
${ }^{30}$ Bittman et al. (2003), for example, find that an increase in the share of women's income in the household is not related to an increase in husbands' housework participation. In their paper, however, although they have a large set of controls, income shares are taken as exogenous variables.

${ }^{31}$ Results in Table 9 show that, on average, the reform reduced by $8-9$ pp women's labor force participation.

${ }^{32}$ For this placebo analysis we use data from the EPH Puntual, a survey that was replaced by the EPH Continua by the end of 2003.
} 
post-treatment period. ${ }^{33}$ In the placebo treatment group, we include women born between 1933 and 1936, while in the placebo control group we have women born between 1942 and 1945. Therefore, the individuals in these placebo treatment and control groups are the same age of individuals included in our original groups (see Tables 2 and 3). If there were an age effect instead of an income effect driving our results, the results of this placebo DD should be similar to those we presented in Tables 7 and 8 .

Tables 10 and 11 present the results of the placebo DD. First, in columns 1 to 12 of Table 10 we check that the evolution of income of the placebo treatment and control groups in the placebo pre and post treatment periods is similar. Indeed, all coefficients are close to zero in magnitude and not statistically different from zero. Results displayed in columns 13 to 16 and 17 to 20 of Table 10 analyze whether there are any effects on the probability of being divorced/separated and on the probability of women being the head of the household, respectively. The estimated effects are very different from the ones in Table 7, often with the opposite sign, although not statistically significant. The same pattern is observed for the sample of married women -Table 11- where all coefficients are close to zero and not statistically significant, except women being the head of the household which goes in the opposite direction. Unfortunately, the EPH Puntual does not include questions about housework sharing within the household.

\section{$7 \quad$ Extensions}

In this Section we provide evidence of heterogeneous effects of the reform by educational attainment (Section 7.1) and we repeat the analysis done in Section 5 using the panel dimension of the EPH (Section 7.2).

\subsection{Heterogeneous Impacts of the Reform by Educational Groups}

In this Section we are interested in checking whether the effects of the reform vary by educational attainment. To analyze the possible heterogeneous effects of the reform we conducted the same regressions as in Section 5 but separating the samples by educational level-high and low, where

\footnotetext{
${ }^{33}$ Results of the placebo DD are robust to different definitions of "pre" and "post" periods.
} 
low education indicates less than high school diploma. The analysis of heterogeneous effects in this Section reveals large differences in the way different educational groups were affected by a permanent income shock. While high-educated women opted-out by increasing their probability of divorce/separation, low-educated opted-in and gained more bargaining power within their marriages.

We start by analyzing the effects of the reform on income by educational attainment. In the interest of brevity, we only report results when controlling for all covariates. Table 13 shows that, although low educated women are in fact the most affected by the reform, so are high educated women. Accordingly, the reform increased the probability of receiving a pension by $50-61 \mathrm{pp}$ for women with low education and by $31-38 \mathrm{pp}$ for those with high education. ${ }^{34}$ Results also indicate that the probability of not having any personal income was reduced by $30-41 \mathrm{pp}$ for women with low education and by $19-26$ pp for women with high education. Despite the high-educated's higher attachment to the formal labor market, which should grant them higher pensions under the reform, results show that the average increase in the monthly personal income was larger for the low educated women-- between 83-92 USD (PPP 2009) - than for the high-educated - between 52-76 USD (PPP 2009). This apparently contradictory result simply confirms that high educated women were less likely to enjoy the benefits from the reform. Results are similar for the subsample of married women. Consistent with the previous results, the low-educated married women saw a larger jump on their relative share of the household's (12.5 pp) and couple's income (15 pp) compared to the high-educated group (6 pp and 5 pp, respectively).

We now discuss the effects of the reform on the probability of divorce/separation by educational attainment. Results reported in the first two columns of Table 14 indicate that the effect of the reform on divorces and separations is mainly driven by the group of high educated women despite being the least affected on average by the reform. For the two subsamples and specifications we find a significant increase in the probability of divorce/separations for the high educated women, between $3.1-5.6 \mathrm{pp}$, while the effect for the low educated is never statistically significant. We can think of at least three non-exclusive explanations for why there are no effects on divorce/separation for the low-educated: (a) given their pre-reform disadvantage within the household, the gains of

\footnotetext{
${ }^{34}$ In our sample only $9 \%$ percent of the observations had imputed monthly income. Research using other data for Argentina (Cruces and Wodon, 2003) express concerns that people with higher incomes are more likely to either underreport or not report. The imputation rate varies by education, a good proxy for income $(6 \%$ for low educated vs $14 \%$ for high educated). The estimated effects for the low-educated where imputation is lower should be regarded as closer to the real values.
} 
a negotiated reallocation of resources may outweigh the gains from divorce or separation; (b) the resources obtained from a pension are not sufficient to live alone; indeed, in the post-reform period the average income of the low educated women in the treated group was around 396 USD (PPP 2009) while the average of the high educated was around 895 USD (PPP 2009); (c) social and cultural factors may be important obstacles that preclude low educated women to take such a decision. ${ }^{35}$ Next, we give evidence that the income increase brought about by the reform led to gains among the low-educated women who remain married.

Finally, we look at differential effects of the reform on the bargaining power of women. Regarding our first indicator i.e. the probability of being the head of household, we find that the the positive effect shown in Section 5 is mainly driven by the effect of the reform on high educated women; while it increases very significantly by $7.1-8.3 \mathrm{pp}$ for the high educated it is not statistically significantly for the low educated (see Table 14). However, when we re-estimate the model for the subsample of married women, the effect of the reform on the probability of being the head of the household is no longer statistically significant for any of the two educational groups. The latter shows that the effect for the high-educated group observed in Table 14 is simply a natural consequence of the increase in divorce/separation for this group. Regarding our second set of indicators i.e. the ones related to the division of housework, we observe an interesting pattern: the negative effect of the reform on the probability that wives are the only responsible for housework is mainly driven by the effects on the low educated women. Again, although coefficients are positive, there is not sufficient evidence to indicate that women's lower responsibility for housework activities is partially compensated by an increase in the husbands' participation.

\subsection{Short-run Effect of the Reform Using Panel Data}

In this Section we exploit the panel dimension of the EPH survey. We restrict our sample to those individuals who are observed in the pre-reform period and can be followed after the reform is implemented. Given that each household in the EPH survey is followed for 1 and a half years, we keep in our sample those individuals interviewed for the first time between the pre-reform quarters 2005-IV and 2006-IV. Hence, the window of analysis using panel data goes from 2005-IV to 2008-I

\footnotetext{
${ }^{35}$ It is conceivable that divorce/separation is not an option for the low-educated as in Lundberg and Pollak (1993).
} 
(10 quarters). ${ }^{36}$ The shorter time window allows us to extend the definition of treatment and control groups, considering additional cohorts that where disregarded in the DD analysis in the previous sections. We define as the treatment group all women born between 1941 and 1945 -i.e., we add the 1945 cohort to those considered in the analysis of Section 5 and Section 7.1. All women in this group already turned 60 by 2005-IV and are potentially eligible since 2007-I to obtain the maximum benefit (i.e., they may include the maximum of 30 years in the moratorium payment schedule, see Table 1). To our control group, we add the 1948 and 1949 cohorts since these cohorts do not turn 60 during the period under study and, hence, are not affected by the reform. Our control group is then composed of women born between 1948 and $1953 .{ }^{37}$

Using the panel has the following advantages: a) it allows controlling for unobserved timeinvariant individual characteristics; b) it allows considering additional cohorts and in this way decrease the age difference between treatment and control groups; However, the approach has its limitations: a) the sample size is much smaller; b) we can only perform an analysis of the very short run effects of the reform since individuals are only followed for a year and a half; c) attrition is likely to be related to the treatment, since women that leave their spouses/partners are more likely to be dropped from the sample, which would create an automatic lower bias in our estimates. ${ }^{38}$ Hence, conditional on observing an individual in the pre-treatment period, we can observe her again, at most, five quarters after the implementation of the reform. In this short period of time many of our outcomes of interest may not change; either because some of the potential beneficiaries of the reform may failed to have effective access to the benefits, or because household dynamics, specially for the elderly, may take more time. Indeed, in the following analysis two outcomes of interest -probability of divorce/separation and probability of being the head of the household- are disregarded since there is almost no variability in these outcomes in the period under analysis. Therefore, we focus exclusively on the effects of the reform on income and the distribution of housework for married women, which, by definition, would not be affected by attrition related to union disolutions.

Table 15 shows the fixed effects estimates of the effects of the reform on women's outcomes for

\footnotetext{
${ }^{36}$ Individuals interviewed for the first time in 2005-IV are followed until 2007-I, while individuals observed for the first time in 2006-IV are followed until 2008-I.

${ }^{37}$ We get the same results if we restrict the analysis to the same cohorts considered in section 5 .

${ }^{38}$ Cruces and Wodon 2003 refer to the problem of attrition in the EPH puntual which is the dataset that preceeded the $\mathrm{EPH}$ continua used in the estimation of the baseline results. Although the EPH continua contains many improvements in relation to the EPH puntual we are concerned that attrition may still be relevant.
} 
the sample of women who are married and remain married throughout the following 5 quarters of the panel. ${ }^{39}$ The reported coefficients in the first row of the table are the DD estimates specified in equation 1 adding an individual fixed effect. Results in columns 1 to 5 of Table 15 confirm that, even in the short run, the implementation of the pension reform led to a significant increase in the probability of receiving a pension (30 pp), a reduction in the percentage of females without any personal income (24 pp), an increase in their monthly personal income (40 USD PPP 2009) and in their participation in the couple's ( $8 \mathrm{pp}$ ) and household's (6 pp) total income. As expected, these short run effects are smaller than the ones reported in Table 6. Consistent with results from Section 7.1, the second and third rows of Table 15 show that in the short-run, the pension reform had an effect on the low-educated's personal income while it did not affect the average personal income of the high-educated (see column 3).

Despite the notable improvements in the position of married women within the household in terms of income -specially for low educated women- we do not find a short run effect of the reform on outcomes related to the distribution of household chores-columns 7 to 9 of table 15 . It is possible that women need to accumulate a certain amount of income before they can bargain with their partners or that the time elapsed since the implementation of the reform is not enough for household members to internalize the change in their relative bargaining power.

\subsubsection{Placebos using the Panel}

We perform a placebo analysis using the panel data in a period prior to the implementation of the reform. As in the previous subsection we consider a period of 10 quarters (2003-IV to 2006-I), and define the period 2003-IV to 2004-IV as the placebo pre-treatment period, and 2005-I to 2006-I as the placebo post-treatment period. To mimic the age structure of our treatment and control groups we define as placebo treatment group cohorts between 1939 to 1943 -which are 60 years old or more in 2003-IV - and as placebo control group cohorts those born between 1946 and 1951 -which are less than 60 years old by $2006-\mathrm{I}$.

Table 16 reports panel data fixed effects estimates using the placebo sample. As predicted,

\footnotetext{
${ }^{39}$ As described in Section 3, we do not observe the individual in 2 of the 5 consecutive quarters.
} 
there are no effects on the probability of pension receipt, on the probability of having no personal income, and on the share of wive's income within the couple or household's income. There is a (small) statistically significant decrease in nominal personal income which may be a consequence of a reduction in the probability of the high-educated women being employed. Importantly, there are no statistically significant changes in outcomes related to the division of household chores within the household.

\subsubsection{Defining treatment and control in the same cohort}

The panel allows us to define a control and treatment group within the same cohorts using information on pre-treatment retirement status. Let's start by restricting the analysis to married women born between 1932 to 1945 observed in the period 2005-IV to 2008-I; all these women already turned 60 by $2005-\mathrm{IV}$. Then, include in the treatment group all women that do not receive a pension in the pre-treatment period and in the control group all women that already receive a pension in the pre-treatment period. Our results with this alternative definition are the same as before: the reform has a large and positive impact on the probability of receiving a pension, a large and negative impact on the probability of not having personal income, and a positive impact on the amount of monthly personal income. Similarly, the short run impacts on the division of household chores are not statistically significant. ${ }^{40}$

\section{Conclusion}

What happens inside the household is often not observable to researchers. However, there seems to be a consensus that processes that occur inside the household have potentially large consequences for economic and social outcomes of individuals and society as a whole. The economic literature has provided evidence that transfer programs can, presumably by altering such processes, have large effects on economic outcomes (e.g. labor force participation, children development). In this paper we focus on senior women - all above the retirement age - and ask whether even relatively small transfers can affect their marital status and bargaining power within the household. We find

\footnotetext{
${ }^{40}$ Results available upon request.
} 
surprising effects in this population; both the union dissolution and outcomes related to bargain power are affected by public transfers.

Our identification strategy comes from estimating the effects of the 2004/2005 Argentinean pension reform on a number of outcomes by differences-and-differences. We use data from the Argentine Continuous Permanent Household Survey (Encuesta Permanente de Hogares Continua) for the years $2004-2009$. The Argentinean pension reform is an interesting application because it not only affected more than 2 million women in Argentina but also because it affected their permanent income substantially; in particular, their income share within the couple increased by an average of $50-55 \%$. This large income shock had an impact on the probability of divorce/separation which increased by $18-19 \%$ for $60-65$ year old women; a large impact on the probability of women headship, which increased by $7-19 \%$ for all women and by $20-22 \%$ amongst married women; and finally, a decrease of $11 \%$ in the likelihood that women are the only responsibles for household chores.

Our result conform with the predictions and results of two main literatures; On the one hand, the increase in the probability of divorce/separation is consistent with the "independent income effect" postulated by sociologists in the context of the divorce literature and later also supported by economists. On the other hand, the results on the probability of women's headship and on the division of household chores are consistent with the literature on the decision and allocation within the household, which predicts that exogenous changes in household members relative incomes affect household demands and outcomes. 


\section{References}

AnderberG, D. And H. Rainer (2011): "Domestic Abuse: Instrumental Violence and Economic Incentives," CESifo Working Paper Series.

Anderson, S. And G. Genicot (2012): "Suicide and Property Rights in India," Working papers, eSocialSciences.

ANSES, O. D. L. S. S. (2012): "La Asignación Universal por Hijo para Protección Social en perspectiva. La política pública como restauradora de derechos," .

Ardington, C., A. Case, And V. Hosegood (2009): "Labor Supply Responses to Large Social Transfers: Longitudinal Evidence from South Africa," American Economic Journal: Applied Economics, 1, 22-48.

Becker, G. (1974): "A theory of marriage," in Economics of the family: Marriage, children, and human capital, UMI, 299-351.

Becker, G. S., E. M. Landes, and R. T. Michael (1977): "An economic analysis of marital instability," The Journal of Political Economy, 1141-1187.

Benigni, M., A. Lieutier, And G. Ludmer (2012): "Evolución reciente de sistema previsional argentino y su impacto en la pobreza de los adultos mayores," Debate Público. Reflexión de Trabajo Social, 2.

Berniell, L. (2012): "Finanzas Públicas y Equidad en América Latina," in Finanzas Públicas para el Desarrollo: Fortaleciendo la Conexión entre Ingresos y Gastos, Corporación Andina de Fomento.

Bertrand, M., S. Mullainathan, And D. Miller (2003): "Public policy and extended families: evidence from pensions in South Africa," The World Bank Economic Review, 17, 27-50.

Bertrand, M., J. Pan, and E. Kamenica (2013): "Gender Identity and Relative Income within Households," Working Paper 19023, National Bureau of Economic Research.

Biddlecom, A. E. and E. A. Kramarow (1998): "Household headship among married women: The roles of economic power, education, and convention," Journal of Family and Economic Issues, $19,367-382$. 
Bittman, M., P. England, L. Sayer, N. Folbre, and G. Matheson (2003): "When Does Gender Trump Money? Bargaining and Time in Household Work," American Journal of Sociology, $109,186-214$.

Bobonis, G. J. (2011): "The Impact of Conditional Cash Transfers on Marriage and Divorce," Economic Development and Cultural Change, 59, 281-312.

Bonke, J. And M. Browning (2009): "The Allocation of Expenditures within the Household: A New Survey," Fiscal Studies, 30, 461-481.

Bosch, M. and J. Guajardo (2012): "Labor Market Impacts of Non-Contributory Pensions: The Case of Argentina's Moratorium," Tech. rep., Inter-American Development Bank.

Bourguignon, F., M. Browning, P.-A. Chiappori, and V. Lechene (1993): "Intra household allocation of consumption: A model and some evidence from French data," Annales d'Economie et de Statistique, 137-156.

Brinig, M. AND D. Allen (2000): "'These boots are made for walking': why most divorce filers are women," American Law and Economics Review, 2, 126-169.

Browning, M. And P. ChiAppori (1998): "Efficient intra-household allocations: A general characterization and empirical tests," Econometrica, 1241-1278.

Browning, M., P. Chiappori, And V. Lechene (2006): "Collective and unitary models: A clarification," Review of Economics of the Household, 4, 5-14.

Browning, M., P. Chiappori, And Y. Weiss (2011): "Family economics," Tel Aviv University, unpublished textbook manuscript.

Cameron, A. C., J. B. Gelbach, and D. L. Miller (2011): "Robust inference with multiway clustering," Journal of Business 83 Economic Statistics, 29.

Chiappori, P.-A. (1988): "Rational household labor supply," Econometrica: Journal of the Econometric Society, 63-90.

Cruces, G. And Q. Wodon (2003): "Risk-adjusted poverty in Argentina: measurement and determinants," . 
Danzer, A. M. (2013): "Benefit Generosity and the Income Effect on Labour Supply: QuasiExperimental Evidence," The Economic Journal.

de Carvalho Filho, I. (2012): "Household Income as a Determinant of Child Labor and School Enrollment in Brazil: Evidence from a Social Security Reform," Economic Development and Cultural Change, 60, 399-435.

D'Elia, V. V., A. Calabria, A. Calero, J. Gaiada, and S. Rottenschweiler (2011): "Análisis de la cobertura previsional del SIPA: protección, inclusión e igualdad," Serie Estudios de la Seguridad Social, Gerencia Estudios de la Seguridad Social, ANSES.

Doiron, D. And S. Mendolia (2011): "The impact of job loss on family dissolution," Journal of Population Economics, 25, 367-398.

Duflo, E. (2000): "Child health and household resources in South Africa: Evidence from the Old Age Pension program," The American Economic Review, 90, 393-398.

EDmonds, E. (2006): "Child labor and schooling responses to anticipated income in South Africa," Journal of Development Economics, 81, 386-414.

Friedman, L. and R. Percival (1976): "Who Sues for Divorce-From Fault through Fiction to Freedom," J. Legal Stud., 5, 61.

GonzÁlez, L. And T. K. Vittanen (2009): "The effect of divorce laws on divorce rates in Europe," European Economic Review, 53, 127 - 138.

GRAY, J. (1998): "Divorce-law changes, household bargaining, and married women's labor supply," American Economic Review, 628-642.

Hankins, S. And M. Hoekstra (2011): "Lucky in life, unlucky in love? The effect of random income shocks on marriage and divorce," Journal of Human Resources, 46, 403-426.

Hoffman, S. And G. Duncan (1995): "The effect of incomes, wages, and AFDC benefits on marital disruption," Journal of Human Resources, 19-41.

ILO (2011): "Key Indicators of the Labour Market (KILM) 6th edition." .

JALOVAARA, M. (2003): "The joint effects of marriage partners' socioeconomic positions on the risk of divorce," Demography, 40, 67-81. 
Levy, S. And N. Schady (2013): "Latin America's Social Policy Challenge: Education, Social Insurance, Redistribution," Journal of Economic Perspectives, 27, 193-218.

Lundberg, S. And R. Pollak (1993): "Separate spheres bargaining and the marriage market," Journal of Political Economy, 988-1010.

- (1996): "Bargaining and distribution in marriage," The Journal of Economic Perspectives, 10, 139-158.

LundberG, S. J., R. A. Pollak, And T. J. Wales (1997): "Do husbands and wives pool their resources? Evidence from the United Kingdom child benefit," Journal of Human Resources, 463480.

Lustig, N. And C. Pessino (2013): "Social Spending and Income Redistribution in Argentina During the 2000s: The Rising Role of Noncontributory Pensions," Working paper, Commitment to Equity.

Manser, M. And M. Brown (1980): "Marriage and household decision-making: A bargaining analysis," International Economic Review, 31-44.

Manzoli, L., P. Villari, G. M Pirone, And A. Boccia (2007): "Marital status and mortality in the elderly: a systematic review and meta-analysis," Social science $\&$ medicine, 64, 77-94.

McElroy, M. (1990): "The empirical content of Nash-bargained household behavior," Journal of human resources, 559-583.

McElroy, M. B. And M. J. Horney (1981): "Nash-bargained household decisions: Toward a generalization of the theory of demand," International Economic Review, 22, 333-349.

PonczeK, V. (2011): "Income and bargaining effects on education and health in Brazil," Journal of Development Economics, 94, 242-253.

Posel, D., J. Fairburn, And F. Lund (2006): "Labour migration and households: A reconsideration of the effects of the social pension on labour supply in South Africa," Economic Modelling, $23,836-853$.

Ross, H., I. Sawhill, And A. MacIntosh (1975): Time of transition: The growth of families headed by women, The Urban Insitute. 
Sayer, L. And S. Bianchi (2000): "Women's Economic Independence and the Probability of Divorce A Review and Reexamination," Journal of Family Issues, 21, 906-943.

Schultz, T. (1990): "Testing the neoclassical model of family labor supply and fertility," Journal of Human Resources, 599-634.

Sienaert, A. (2008): "The labour supply effects of the South African state old age pension: Theory, evidence and implications," Tech. rep., Southern Africa Labour and Development Research Unit, University of Cape Town.

Thomas, D. (1990): "Intra-household resource allocation: An inferential approach," Journal of human resources, 635-664.

Tornarolli, L. And A. Conconi (2007): "Informalidad y movilidad laboral: un análisis empírico para Argentina," Documento de Trabajo, 59.

Villacorta, L. (2013): "Robust Standard Errors to Spatial and Time Dependence in Nearly Square Panels," Mimeo.

Weiss, Y. (1997): "The formation and dissolution of families: Why marry? Who marries whom? And what happens upon divorce," Handbook of population and family economics, 1, 81-123.

Weiss, Y. AND R. WILlis (1997): "Match quality, new information, and marital dissolution," Journal of Labor Economics, 293-329. 


\subsection{Tablas and Figures}

Table 1: Examples of the different impact of the pension reform across cohorts

\begin{tabular}{ccccc}
\hline Birth year & $\begin{array}{c}\text { Year she is } 18 \\
\text { years old }\end{array}$ & $\begin{array}{c}\text { Year she is } 60 \\
\text { years old }\end{array}$ & $\begin{array}{c}\text { Years allowed to include in } \\
\text { the payment schedule } \\
\min (1993-\text { column }(2), 30)\end{array}$ & $\begin{array}{c}\text { Effective years of SS } \\
\text { contributions needed to retire at } 60\end{array}$ \\
30-min(1993- column $(2), 30)$ & $(4)$ \\
\hline 1941 & 1959 & $(3)$ & 30 & 0 \\
1944 & 1962 & 2001 & 30 & 0 \\
1950 & 1968 & 2004 & 25 & 5 \\
1953 & 1971 & 2013 & 22 & 8 \\
\hline
\end{tabular}

Required years of effective social security contributions (Column 5$)=30-\min \{1993-($ birth year +18$), 30\}$

Table 2: Definition of treated and control groups

\begin{tabular}{|c|c|c|}
\hline Women & Pre treatment $(2004-2006)$ & Post treatment $(2007-2009)$ \\
\hline $\begin{array}{l}\text { Treated cohorts } \\
\text { born 1941-1944 }\end{array}$ & ages 60-65 & ages 63-68 \\
\hline $\begin{array}{l}\text { Control cohorts } \\
\text { born 1950-1953 }\end{array}$ & ages 51-56 $54-59$ \\
\hline
\end{tabular}

Table 3: Placebo DD: Definition of treated and control groups

\begin{tabular}{|c|c|c|}
\hline Women & $\begin{array}{c}\text { Placebo pre treatment } \\
(1996-1998)\end{array}$ & $\begin{array}{c}\text { Placebo post treatment } \\
(1999-2001)\end{array}$ \\
\hline $\begin{array}{c}\text { Placebo treated cohorts } \\
\text { born 1933-1936 }\end{array}$ & ages 60-65 & ages 63-68 \\
\hline $\begin{array}{c}\text { Placebo control cohorts } \\
\text { born 1942-1945 }\end{array}$ & ages 51-56 & ages 54-59 \\
\hline
\end{tabular}


Table 4: Mean

\begin{tabular}{|c|c|c|c|c|c|c|}
\hline \multirow{3}{*}{ Variable } & \multirow{2}{*}{\multicolumn{2}{|c|}{ Control cohorts }} & \multirow{2}{*}{\multicolumn{2}{|c|}{ Treated cohorts }} & \multirow{2}{*}{\multicolumn{2}{|c|}{ All sample }} \\
\hline & & & & & & \\
\hline & $2004-06$ & \multicolumn{2}{|c|}{ 2007-092004-06 } & \multicolumn{3}{|c|}{ 2007-092004-06 2007-09 } \\
\hline \multicolumn{7}{|c|}{ All women } \\
\hline Pension recipient & 0.08 & 0.12 & 0.30 & 0.77 & 0.18 & 0.39 \\
\hline No personal income & 0.36 & 0.34 & 0.40 & 0.12 & 0.38 & 0.25 \\
\hline Personal income (Argentine Pesos: AR $\$$ ) & 510 & 1017 & 412 & 928 & 468 & 980 \\
\hline Personal income (2009 PPP USD) & 341 & 615 & 275 & 562 & 313 & 593 \\
\hline Divorced or separated & 0.16 & 0.15 & 0.10 & 0.10 & 0.13 & 0.13 \\
\hline Head of household & 0.32 & 0.36 & 0.38 & 0.44 & 0.35 & 0.40 \\
\hline Woman is the only responsible for housework & 0.37 & 0.39 & 0.44 & 0.45 & 0.40 & 0.42 \\
\hline Education $($ high $=1$, low $=0)$ & 0.45 & 0.46 & 0.32 & 0.33 & 0.39 & 0.40 \\
\hline Born abroad & 0.07 & 0.08 & 0.10 & 0.10 & 0.08 & 0.09 \\
\hline Live with partner & 0.09 & 0.09 & 0.07 & 0.07 & 0.08 & 0.08 \\
\hline Married & 0.58 & 0.57 & 0.52 & 0.48 & 0.56 & 0.53 \\
\hline Widow & 0.08 & 0.11 & 0.23 & 0.26 & 0.15 & 0.17 \\
\hline Single & 0.08 & 0.09 & 0.08 & 0.09 & 0.08 & 0.09 \\
\hline Active (in the labor market) & 0.61 & 0.56 & 0.37 & 0.24 & 0.50 & 0.43 \\
\hline \multicolumn{7}{|c|}{ Divorced \& married } \\
\hline Pension recipient & 0.04 & 0.06 & 0.17 & 0.72 & 0.09 & 0.31 \\
\hline No personal income & 0.41 & 0.39 & 0.52 & 0.16 & 0.45 & 0.31 \\
\hline Personal income (Argentine Pesos: AR $\$$ ) & 481 & 958 & 333 & 783 & 424 & 893 \\
\hline Personal income (2009 PPP USD) & 321 & 580 & 222 & 474 & 283 & 541 \\
\hline Divorced or separated & 0.19 & 0.18 & 0.14 & 0.16 & 0.17 & 0.18 \\
\hline Head of household & 0.23 & 0.25 & 0.18 & 0.23 & 0.21 & 0.24 \\
\hline Woman is the only responsible for housework & 0.37 & 0.39 & 0.44 & 0.43 & 0.40 & 0.40 \\
\hline Education $($ high $=1$, low $=0)$ & 0.46 & 0.47 & 0.34 & 0.33 & 0.41 & 0.42 \\
\hline Born abroad & 0.07 & 0.09 & 0.10 & 0.11 & 0.08 & 0.09 \\
\hline Active (in the labor market) & 0.58 & 0.55 & 0.34 & 0.22 & 0.49 & 0.43 \\
\hline \multicolumn{7}{|c|}{ Married } \\
\hline Pension recipient & 0.04 & 0.06 & 0.16 & 0.72 & 0.09 & 0.31 \\
\hline No personal income & 0.48 & 0.46 & 0.57 & 0.18 & 0.52 & 0.35 \\
\hline Personal income (Argentine Pesos: AR $\$$ ) & 412 & 849 & 298 & 722 & 367 & 801 \\
\hline Personal income (2009 PPP USD) & 276 & 514 & 199 & 436 & 245 & 485 \\
\hline Wife's share of income within household & 0.21 & 0.21 & 0.18 & 0.28 & 0.20 & 0.24 \\
\hline Wife's share of income within couple & 0.26 & 0.27 & 0.22 & 0.34 & 0.24 & 0.29 \\
\hline Head of household & 0.08 & 0.11 & 0.07 & 0.11 & 0.07 & 0.11 \\
\hline Wife is the only responsible for housework & 0.37 & 0.40 & 0.44 & 0.41 & 0.40 & 0.40 \\
\hline Husband does some housework & 0.24 & 0.27 & 0.30 & 0.35 & 0.26 & 0.30 \\
\hline Husband responsible for housework & 0.11 & 0.15 & 0.13 & 0.18 & 0.11 & 0.16 \\
\hline Have domestic service or external help & 0.04 & 0.05 & 0.03 & 0.03 & 0.04 & 0.04 \\
\hline Education $($ high $=1$, low $=0)$ & 0.45 & 0.46 & 0.33 & 0.31 & 0.40 & 0.40 \\
\hline Born abroad & 0.07 & 0.09 & 0.11 & 0.11 & 0.09 & 0.09 \\
\hline Couple's age difference & 2.65 & 2.51 & 2.50 & 2.50 & 2.59 & 2.50 \\
\hline Couple's education difference & 0.06 & 0.06 & -0.15 & -0.16 & -0.03 & -0.02 \\
\hline Active (in the labor market) & 0.52 & 0.50 & 0.30 & 0.18 & 0.44 & 0.38 \\
\hline Observations & 13271 & 13359 & 9537 & 9680 & 23008 & 23039 \\
\hline
\end{tabular}


Table 5: Effects of the reform on income

\begin{tabular}{|c|c|c|c|c|c|c|c|c|c|c|c|c|}
\hline & \multicolumn{4}{|c|}{ Probability of receiving a pension } & \multicolumn{4}{|c|}{ Probability of not having any personal income } & \multicolumn{4}{|c|}{ Women's personal income (dollars PPP) } \\
\hline & \multicolumn{2}{|c|}{$\begin{array}{l}\text { Whole sample } \\
\mathrm{d}+\mathrm{m}+\mathrm{w}+\mathrm{s}\end{array}$} & \multicolumn{2}{|c|}{$\begin{array}{l}\text { Divorced \& married } \\
\qquad \mathrm{d}+\mathrm{m}\end{array}$} & \multicolumn{2}{|c|}{$\begin{array}{l}\text { Whole sample } \\
\qquad \mathrm{d}+\mathrm{m}+\mathrm{w}+\mathrm{s}\end{array}$} & \multicolumn{2}{|c|}{$\begin{array}{l}\text { Divorced \& married } \\
\qquad \mathrm{d}+\mathrm{m}\end{array}$} & \multicolumn{2}{|c|}{$\begin{array}{c}\text { Whole sample } \\
\mathrm{d}+\mathrm{m}+\mathrm{w}+\mathrm{s}\end{array}$} & \multicolumn{2}{|c|}{$\begin{array}{l}\text { Divorced \& married } \\
\qquad \mathrm{d}+\mathrm{m}\end{array}$} \\
\hline & (1) & $(2)$ & (3) & (4) & (5) & $(6)$ & (7) & $(8)$ & (9) & $(10)$ & (11) & $(12)$ \\
\hline Post*Treated & $\begin{array}{c}0.437^{* * *} \\
(0.0135)\end{array}$ & $\begin{array}{l}0.434^{* * *} \\
(0.0135)\end{array}$ & $\begin{array}{c}0.535^{* * *} \\
(0.0176)\end{array}$ & $\begin{array}{l}0.532^{* * *} \\
(0.0176)\end{array}$ & $\begin{array}{c}-0.269^{* * *} \\
(0.0122)\end{array}$ & $\begin{array}{c}-0.267^{* * *} \\
(0.0120)\end{array}$ & $\begin{array}{c}-0.361^{* * *} \\
(0.0168)\end{array}$ & $\begin{array}{c}-0.362^{* * *} \\
(0.0168)\end{array}$ & $\begin{array}{c}73.12^{* * *} \\
(13.47)\end{array}$ & $\begin{array}{c}68.47^{* * *} \\
(12.69)\end{array}$ & $\begin{array}{c}60.97^{* * *} \\
(14.67)\end{array}$ & $\begin{array}{c}65.64^{* * *} \\
(13.66)\end{array}$ \\
\hline Education high (dummy) & & $\mathrm{x}$ & & $\mathrm{x}$ & & $\mathrm{x}$ & & $\mathrm{x}$ & & $\mathrm{x}$ & & $\mathrm{x}$ \\
\hline Born abroad & & $\mathrm{x}$ & & $\mathrm{x}$ & & $\mathrm{x}$ & & $\mathrm{x}$ & & $\mathrm{x}$ & & $\mathrm{x}$ \\
\hline Region fixed effects & & $\mathrm{x}$ & & $\mathrm{x}$ & & $\mathrm{x}$ & & $\mathrm{x}$ & & $\mathrm{x}$ & & $\mathrm{x}$ \\
\hline Observations & 46,047 & 46,047 & 34,039 & 34,039 & 46,047 & 46,047 & 34,039 & 34,039 & 46,047 & 46,047 & 34,039 & 34,039 \\
\hline Obs. in treatment group & 19,217 & 19,217 & 12,554 & 12,554 & 19,217 & 19,217 & 12,554 & 12,554 & 19,217 & 19,217 & 12,554 & 12,554 \\
\hline Obs. in control group & 26,830 & 26,830 & 21,485 & 21,485 & 26,830 & 26,830 & 21,485 & 21,485 & 26,830 & 26,830 & 21,485 & 21,485 \\
\hline Mean dependent variable & 0.3 & 0.3 & 0.17 & 0.17 & 0.4 & 0.4 & 0.52 & 0.52 & 275 & 275 & 222.3 & 222.3 \\
\hline
\end{tabular}

iv The dependent variables are: a dummy that equals one when the woman receives a pension (columns 1-4); a dummy that equals one when she has no personal income (columns 5-8);

and the woman's monthly personal income in international 2009 PPP dollars (columns 9-12). The coefficient on Post*Treated is the estimated parameter $\beta$ of equation 1 which is the DD estimates (OLS) of the effect of the reform on each of the outcomes. Period 2004-2006 is the pre-treatment period and period 2007-2009 is the post-treatment period. The treatment group includes all women born between 1941 and 1944, and the control group women born between 1950 and 1953 . All regressions include the following control variables: cohort, year and quarter fixed effects, interactions between the last two, and a dummy that indicates whether the woman belongs to the top $1 \%$ of personal income. The whole sample includes all women regardless of their marital status. Other individual characteristics in the even columns are: a dummy variable that equals one if the maximum level of education attained is at least a high school diploma; a dummy variable that equals one if the woman was born abroad; and regions fixed effects (29 urban areas). All results come from regressions using as sample weights the variable pondera in the EPH. The sample "divorced \& married" is restricted to married (m) and divorced/separated women (d), i.e. it excludes singles (s) and widows (w). Data source: Argentine Continuous Permanent Household Survey (Encuesta Permanente de Hogares Continua, EPH). Robust standard errors clustered at cohort-year-quarter in parentheses. ${ }^{* * *} \mathrm{p}<0.01,{ }^{* *} \mathrm{p}<0.05,{ }^{*} \mathrm{p}<0.1$. 
Table 6: Effects of the reform on income. Sample of married women

\begin{tabular}{|c|c|c|c|c|c|c|c|c|c|c|c|}
\hline & & \multicolumn{2}{|c|}{$\begin{array}{c}\text { Probability of } \\
\text { receiving a pension }\end{array}$} & \multicolumn{2}{|c|}{$\begin{array}{l}\text { Wife does not have } \\
\text { personal income }\end{array}$} & \multicolumn{2}{|c|}{$\begin{array}{c}\text { Wife's personal } \\
\text { income (PPP Dollars) }\end{array}$} & \multicolumn{2}{|c|}{$\begin{array}{l}\text { Wife's share of income } \\
\text { within household }\end{array}$} & \multicolumn{2}{|c|}{$\begin{array}{l}\text { Wife's share of income } \\
\text { within couple }\end{array}$} \\
\hline & & (1) & $(2)$ & (3) & (4) & (5) & (6) & (7) & (8) & $(9)$ & (10) \\
\hline & \multirow{2}{*}{ Post*treated } & $0.546^{* * *}$ & $0.544^{* * *}$ & $-0.387^{* * *}$ & $-0.390 * * *$ & $64.02^{* * *}$ & $71.14^{* * *}$ & $0.101^{* * *}$ & $0.102^{* * *}$ & $0.110^{* * *}$ & $0.112^{* * *}$ \\
\hline & & $(0.0179)$ & $(0.0178)$ & $(0.0186)$ & $(0.0179)$ & $(16.87)$ & $(15.55)$ & $(0.00931)$ & $(0.00899)$ & $(0.0107)$ & $(0.0103)$ \\
\hline & Education high (dummy) & & $\mathrm{x}$ & & $\mathrm{x}$ & & $\mathrm{x}$ & & $\mathrm{x}$ & & $\mathrm{x}$ \\
\hline & Region fixed effects & & $\mathrm{x}$ & & $\mathrm{x}$ & & $\mathrm{x}$ & & $\mathrm{x}$ & & $\mathrm{x}$ \\
\hline & Couple's age difference & & $\mathrm{x}$ & & $\mathrm{x}$ & & $\mathrm{x}$ & & $\mathrm{x}$ & & $\mathrm{x}$ \\
\hline & Couple's education difference & & $\mathrm{x}$ & & $\mathrm{x}$ & & $\mathrm{x}$ & & $\mathrm{x}$ & & $\mathrm{x}$ \\
\hline & Born abroad & & $\mathrm{x}$ & & $\mathrm{x}$ & & $\mathrm{x}$ & & $\mathrm{x}$ & & $\mathrm{x}$ \\
\hline \multirow[t]{4}{*}{$\underset{f}{\oplus}$} & Observations & 27,157 & 27,157 & 27,157 & 27,157 & 27,157 & 27,157 & 26,954 & 26,954 & 26,544 & 26,544 \\
\hline & Obs. in treatment group & 10,304 & 10,304 & 10,304 & 10,304 & 10,304 & 10,304 & 10,304 & 10,304 & 10,304 & 10,304 \\
\hline & Obs. in control group & 16,853 & 16,853 & 16,853 & 16,853 & 16,853 & 16,853 & 16,853 & 16,853 & 16,853 & 16,853 \\
\hline & Mean dependent variable & 0.16 & 0.16 & 0.57 & 0.57 & 199.3 & 199.3 & 0.18 & 0.18 & 0.22 & 0.22 \\
\hline
\end{tabular}

The dependent variables are: a dummy that equals one when the wife receives a pension (columns 1-2), a dummy that equals one when she has no personal income (columns 3-4), wife's personal income in international 2009 PPP dollars (columns 5-6), the share of wife's income within the household (columns 7-8) and within the couple (columns 9-10). The coefficient on Post*Treated is the estimated parameter $\beta$ of equation 1 which is the DD estimates (OLS) of the effect of the reform on each of the outcomes. Period 2004-2006 is the pre-treatment period and period 2007-2009 is the post-treatment period. The treatment group includes all women born between 1941 and 1944, and the control group women born between 1950 and 1953. All regressions include the following control variables: cohort, year and quarter fixed effects, interactions between the last two, and a dummy that indicates whether the woman belongs to the top $1 \%$ of personal income. Other individual characteristics in the even columns are: a dummy variable that equals one if the maximum level of education attained is at least a high school diploma; a dummy variable that equals one if the woman was born abroad; regions fixed effects ( 29 urban areas); and differences between spouses' age and level of education attained. All results come from regressions using as sample weights the variable pondera in the EPH. Data source: Argentine Continuous Permanent Household Survey (Encuesta Permanente de Hogares Continua, EPH). Robust standard errors clustered at cohort-year-quarter in parentheses. ${ }^{* * *} \mathrm{p}<0.01,{ }^{* *} \mathrm{p}<0.05, *$ $\mathrm{p}<0.1$. 
Table 7: Effects of the reform on the probability of being divorced/separated, and the bargaining power of women

\begin{tabular}{|c|c|c|c|c|c|c|c|c|c|c|c|c|}
\hline & \multicolumn{4}{|c|}{ Probability of women being divorced/separated } & \multicolumn{4}{|c|}{ Probability of women being the head of the household } & \multicolumn{4}{|c|}{ Woman is the only responsible for housework } \\
\hline & \multicolumn{2}{|c|}{$\begin{array}{c}\text { Whole sample } \\
\mathrm{d}+\mathrm{m}+\mathrm{w}+\mathrm{s}\end{array}$} & \multicolumn{2}{|c|}{$\begin{array}{l}\text { Divorced \& married } \\
\qquad \mathrm{d}+\mathrm{m}\end{array}$} & \multicolumn{2}{|c|}{$\begin{array}{l}\text { Whole sample } \\
\mathrm{d}+\mathrm{m}+\mathrm{w}+\mathrm{s}\end{array}$} & \multicolumn{2}{|c|}{$\begin{array}{l}\text { Divorced \& married } \\
\qquad \mathrm{d}+\mathrm{m}\end{array}$} & \multicolumn{2}{|c|}{$\begin{array}{l}\text { Whole sample } \\
\mathrm{d}+\mathrm{m}+\mathrm{w}+\mathrm{s}\end{array}$} & \multicolumn{2}{|c|}{$\begin{array}{l}\text { Divorced \& married } \\
\qquad \mathrm{d}+\mathrm{m}\end{array}$} \\
\hline & $(1)$ & $(2)$ & $(3)$ & $(4)$ & $(5)$ & $(6)$ & $(7)$ & $(8)$ & $(9)$ & $(10)$ & $(11)$ & $(12)$ \\
\hline Post*treated & $\begin{array}{l}0.0180^{* *} \\
(0.00829)\end{array}$ & $\begin{array}{l}0.0183^{* *} \\
(0.00829)\end{array}$ & $\begin{array}{l}0.0254^{* *} \\
(0.0113)\end{array}$ & $\begin{array}{c}0.0269^{* *} \\
(0.0114)\end{array}$ & $\begin{array}{c}0.0284^{* * *} \\
(0.0107)\end{array}$ & $\begin{array}{l}0.0277^{* *} \\
(0.0107)\end{array}$ & $\begin{array}{c}0.0321^{* * *} \\
(0.0112)\end{array}$ & $\begin{array}{c}0.0334^{* * *} \\
(0.0114)\end{array}$ & $\begin{array}{l}-0.0126 \\
(0.0121)\end{array}$ & $\begin{array}{l}-0.0121 \\
(0.0121)\end{array}$ & $\begin{array}{l}-0.0257^{*} \\
(0.0140)\end{array}$ & $\begin{array}{l}-0.0244^{*} \\
(0.0141)\end{array}$ \\
\hline Education high (dummy) & & $\mathrm{x}$ & & $\mathrm{x}$ & & $\mathrm{x}$ & & $\mathrm{x}$ & & $\mathrm{x}$ & & $\mathrm{x}$ \\
\hline Region fixed effects & & $\mathrm{x}$ & & $\mathrm{x}$ & & $\mathrm{x}$ & & $\mathrm{x}$ & & $\mathrm{x}$ & & $\mathrm{x}$ \\
\hline Born abroad & & $\mathrm{x}$ & & $\mathrm{x}$ & & $\mathrm{x}$ & & $\mathrm{x}$ & & $\mathrm{x}$ & & $\mathrm{x}$ \\
\hline Observations & 46,047 & 46,047 & 34,039 & 34,039 & 46,047 & 46,047 & 34,039 & 34,039 & 46,047 & 46,047 & 34,039 & 34,039 \\
\hline Obs. in treatment group & 19,217 & 19,217 & 12,554 & 12,554 & 19,217 & 19,217 & 12,554 & 12,554 & 19,217 & 19,217 & 12,554 & 12,554 \\
\hline Obs. in control group & 26,830 & 26,830 & 21,485 & 21,485 & 26,830 & 26,830 & 21,485 & 21,485 & 26,830 & 26,830 & 21,485 & 21,485 \\
\hline Mean dependent variable & 0.10 & 0.10 & 0.14 & 0.14 & 0.38 & 0.38 & 0.18 & 0.18 & 0.44 & 0.44 & 0.44 & 0.44 \\
\hline
\end{tabular}

and a dummy that equals one if she is the only household member responsible for housework (Columns 9-12). The coefficient on Post*Treated is the estimated parameter $\beta$ of equation 1 which is the DD estimates (OLS) of the effect of the reform on each of the outcomes. Period 2004-2006 is the pre-treatment period and period 2007-2009 is the post-treatment period. The treatment group includes all women born between 1941 and 1944, and the control group women born between 1950 and 1953 . All regressions include the following control variables: cohort, year and quarter fixed effects, interactions between the last two, and a dummy that indicates whether the woman belongs to the top $1 \%$ of personal income. Other individual characteristics in the even columns are: a dummy variable that equals one if the maximum level of education attained is at least a high school diploma; a dummy variable that equals one if the woman was born abroad; and regions fixed effects (29 urban areas). All results come from regressions using as sample weights the variable pondera in the EPH. The "whole sample" includes all women regardless of their marital status. The sample "divorced \& married" is restricted to married (m) and divorced/separated women (d), i.e. it excludes singles (s) and widows (w). Data source: Argentine Continuous Permanent Household Survey (Encuesta Permanente de Hogares Continua, EPH). Robust standard errors clustered at cohort-year-quarter in parentheses. $* * * \mathrm{p}<0.01, * * \mathrm{p}<0.05, * \mathrm{p}<0.1$. 
Table 8: Effects of the reform on the bargaining power of women Sample of married women

\begin{tabular}{|c|c|c|c|c|c|c|c|c|c|c|c|}
\hline & & \multicolumn{2}{|c|}{$\begin{array}{l}\text { Wife is the head } \\
\text { of household }\end{array}$} & \multicolumn{2}{|c|}{$\begin{array}{l}\text { Wife is the only } \\
\text { responsible for housework }\end{array}$} & \multicolumn{2}{|c|}{$\begin{array}{l}\text { Domestic service } \\
\text { or external help }\end{array}$} & \multicolumn{2}{|c|}{$\begin{array}{c}\text { Husband does } \\
\text { some or most housework }\end{array}$} & \multicolumn{2}{|c|}{$\begin{array}{l}\text { Husband does } \\
\text { most housework }\end{array}$} \\
\hline & & (1) & $(2)$ & (3) & $(4)$ & (5) & (6) & (7) & (8) & (9) & (10) \\
\hline & Post*treated & $0.0134^{*}$ & $0.0145^{*}$ & $-0.0502^{* * *}$ & $-0.0497^{* * *}$ & 0.0049 & 0.0060 & 0.0237 & 0.0251 & 0.0140 & 0.0163 \\
\hline & & $(0.00807)$ & $(0.00769)$ & $(0.0150)$ & $(0.0151)$ & $(0.0054)$ & $(0.0053)$ & $(0.0170)$ & $(0.0168)$ & $(0.0121)$ & $(0.0122)$ \\
\hline & Education high (dummy) & & $\mathrm{x}$ & & $\mathrm{x}$ & & $\mathrm{x}$ & & $\mathrm{x}$ & & $\mathrm{x}$ \\
\hline & Region fixed effects & & $\mathrm{x}$ & & $\mathrm{x}$ & & $\mathrm{x}$ & & $\mathrm{x}$ & & $\mathrm{x}$ \\
\hline & Couple's age difference & & $\mathrm{x}$ & & $\mathrm{x}$ & & $\mathrm{x}$ & & $\mathrm{x}$ & & $\mathrm{x}$ \\
\hline & Couple's education difference & & $\mathrm{x}$ & & $\mathrm{x}$ & & $\mathrm{x}$ & & $\mathrm{x}$ & & $\mathrm{x}$ \\
\hline & Born abroad & & $\mathrm{x}$ & & $\mathrm{x}$ & & $\mathrm{x}$ & & $\mathrm{x}$ & & $\mathrm{x}$ \\
\hline \multirow{5}{*}{ g } & Observations & 27,157 & 27,157 & 27,157 & 27,157 & 27,157 & 27,157 & 27,157 & 27,157 & 27,157 & 27,157 \\
\hline & Obs. in treatment group & 10,304 & 10,304 & 10,304 & 10,304 & 10,304 & 10,304 & 10,304 & 10,304 & 10,304 & 10,304 \\
\hline & Obs. in control group & 16,853 & 16,853 & 16,853 & 16,853 & 16,853 & 16,853 & 16,853 & 16,853 & 16,853 & 16,853 \\
\hline & Mean dependent variable & 0.07 & 0.07 & 0.44 & 0.44 & 0.03 & 0.03 & 0.30 & 0.30 & 0.13 & 0.13 \\
\hline & $\begin{array}{l}\text { The dependent variables are: a d } \\
\text { member responsible for housewor } \\
5-6 \text { ), a dummy variable that equa } \\
\text { in charge of most of the housewo } \\
\text { of the effect of the reform on each } \\
\text { group includes all women born b } \\
\text { variables: cohort, year and quar } \\
\text { personal income. Other individua } \\
\text { a high school diploma; a dummy } \\
\text { age and level of education attaine } \\
\text { Permanent Household Survey (E } \\
\mathrm{p}<0.01,{ }^{* *} \mathrm{p}<0.05,{ }^{*} \mathrm{p}<0.1 \text {. }\end{array}$ & $\begin{array}{l}\text { mmy that eq } \\
\text { (column } 3- \\
\text { s one if the } \\
\text { (columns s } \\
\text { of the outco } \\
\text { tween } 1941 \\
\text { er fixed effec } \\
\text { characterist } \\
\text { variable that } \\
\text { All results } \\
\text { cuesta Perm }\end{array}$ & $\begin{array}{l}\text { uals one if th } \\
\text { ), a dummy } \\
\text {-10). The cc } \\
\text { nes. Period } \\
\text { nd } 1944 \text {, an } \\
\text { ts, interacti } \\
\text { ics in the eve } \\
\text { equals one } \\
\text { come from } r \\
\text { anente de } \mathrm{H}\end{array}$ & $\begin{array}{l}\text { e wife is the } \mathrm{h} \\
\text { variable that } \\
\text { s or is in chat } \\
\text { efficient on P } \\
\text { 2004-2006 is t } \\
\text { d the control } \\
\text { ns between t } \\
\text { n columns ar } \\
\text { f the woman } \\
\text { egressions usi } \\
\text { ogares Contil }\end{array}$ & $\begin{array}{l}\text { ad of the hous } \\
\text { quals one if } t \\
\text { e of most of } t \\
\text { st* Treated is } \\
\text { e pre-treatmer } \\
\text { roup women } \\
\text { e last two, an } \\
\text { a dummy var } \\
\text { as born abroc } \\
\text { as sample we } \\
\text { aa, EPH). Ro }\end{array}$ & $\begin{array}{l}\text { hold (Col } \\
\text { e househo } \\
\text { e housewo } \\
\text { he estimat } \\
\text { t period al } \\
\text { orn betwe } \\
\text { a dumm } \\
\text { able that } \\
\text { d; regions } \\
\text { ghts the v } \\
\text { ust stand }\end{array}$ & $\begin{array}{l}\text { mns 1-2), a } \\
\text { has domes } \\
k \text { (columns } \\
\text { d paramete } \\
\text { period } 20 \\
1950 \text { and } \\
\text { that indic } \\
\text { uals one if } \\
\text { xed effects } \\
\text { iable pond } \\
\text { d errors cl }\end{array}$ & $\begin{array}{l}\text { dummy th } \\
\text { tic service } \\
7-8 \text { ) and a } \\
\beta \text { of equa } \\
7-2009 \text { is } t \\
\text { 1953. All } \\
\text { ites whethe } \\
\text { the maxim } \\
\text { (29 urban } \\
r a \text { in the E } \\
\text { istered at }\end{array}$ & $\begin{array}{l}\text { equals one if } \\
\text { external help } \\
\text { mmy variabl } \\
\text { n } 1 \text { which is } \\
\text { post-treatme } \\
\text { ressions incle } \\
\text { he woman b } \\
\text { level of educ } \\
\text { as); and diffe } \\
\text {. Data sourc } \\
\text { ort-year-qua }\end{array}$ & $\begin{array}{l}\text { e is the on } \\
\text { or housew } \\
\text { that equal } \\
\text { e DD estin } \\
\text { t period.Tl } \\
\text { le the follo } \\
\text { longs to th } \\
\text { tion attain } \\
\text { ences betw } \\
\text { Argentine } \\
\text { er in pare }\end{array}$ & $\begin{array}{l}\text { household } \\
\mathrm{k} \text { (columns } \\
\text { one if he is } \\
\text { tates (OLS) } \\
\text { e treatment } \\
\text { ting control } \\
\text { top } 1 \% \text { of } \\
\text { d is at least } \\
\text { en spouses' } \\
\text { Continuous } \\
\text { theses. *** }\end{array}$ \\
\hline
\end{tabular}


Table 9: The effect of the reform on the labor status Sample of married women

\begin{tabular}{lcccccc}
\cline { 2 - 7 } & \multicolumn{2}{c}{ All married women } & \multicolumn{2}{c}{ Low education } & \multicolumn{2}{c}{ High education } \\
& $(1)$ & $(2)$ & $(3)$ & $(4)$ & $(5)$ & $(6)$ \\
\hline \multirow{2}{*}{ Post*treated } & $-0.0863^{* * *}$ & $-0.0806^{* * *}$ & $-0.0727^{* * *}$ & $-0.0679^{* * *}$ & $-0.114^{* * *}$ & $-0.108^{* * *}$ \\
& $(0.0151)$ & $(0.0145)$ & $(0.0175)$ & $(0.0175)$ & $(0.0257)$ & $(0.0256)$ \\
\hline
\end{tabular}

\begin{tabular}{|c|c|c|c|c|c|c|}
\hline Education high (dummy) & & $\mathrm{x}$ & & & & \\
\hline Region fixed effects & & $\mathrm{x}$ & & $\mathrm{x}$ & & $\mathrm{x}$ \\
\hline Couple's age difference & & $\mathrm{x}$ & & $\mathrm{x}$ & & $\mathrm{x}$ \\
\hline Couple's education difference & & $\mathrm{x}$ & & $\mathrm{x}$ & & $\mathrm{x}$ \\
\hline Born abroad & & $\mathrm{x}$ & & $\mathrm{x}$ & & $\mathrm{x}$ \\
\hline Observations & 27,122 & 27,122 & 16,466 & 16,466 & 10,656 & 10,656 \\
\hline Obs. in treatment group & 10,293 & 10,293 & 7,049 & 7,049 & 3,244 & 3,244 \\
\hline Obs. in control group & 16,829 & 16,829 & 9,417 & 9,417 & 7,412 & 7,412 \\
\hline Mean dependent variable & 0.37 & 0.37 & 0.33 & 0.33 & 0.44 & 0.44 \\
\hline
\end{tabular}

The dependent variable is a dummy that equals one if the woman is economically "active". This variable uses the definition proposed in the EPH which is constructed from survey variables related to labor force participation. The coefficient on Post*Treated is the estimated parameter $\beta$ of equation 1 which is the DD estimates (OLS) of the effect of the reform on each of the outcomes. Results in columns 3-6 are obtained separating the samples by educational level-high and low, where low education indicates less than high than high school diploma. Period 2004-2006 is the pre-treatment period and period 2007-2009 is the post-treatment period. The treatment group includes all women born between 1941 and 1944, and the control group women born between 1950 and 1953. All regressions include the following control variables: cohort, year and quarter fixed effects, interactions between the last two, and a dummy that indicates whether the woman belongs to the top $1 \%$ of personal income. Other individual characteristics in the even columns are: a dummy variable that equals one if the maximum level of education attained is at least a high school diploma; a dummy variable that equals one if the woman was born abroad; regions fixed effects (29 urban areas); and differences between spouses' age and level of education attained. All results come from regressions using as sample weights the variable pondera in the EPH. Data source: Argentine Continuous Permanent Household Survey (Encuesta Permanente de Hogares Continua, EPH). Robust standard errors clustered at cohort-year-quarter in parentheses. ${ }^{* * *}$ $\mathrm{p}<0.01,{ }^{*} \mathrm{p}<0.05,{ }^{*} \mathrm{p}<0.1$. 
Table 10: Placebo using pre-treatment data (1996-2001)

\begin{tabular}{|c|c|c|c|c|c|c|c|c|c|c|c|c|}
\hline & \multicolumn{4}{|c|}{ Probability of receiving a pension } & \multicolumn{4}{|c|}{ Probability of not having any personal income } & \multicolumn{4}{|c|}{ Women's personal income (Dollars PPP) } \\
\hline & \multicolumn{2}{|c|}{$\begin{array}{l}\text { Whole sample } \\
\mathrm{d}+\mathrm{m}+\mathrm{w}+\mathrm{s}\end{array}$} & \multicolumn{2}{|c|}{$\begin{array}{l}\text { Divorced \& married } \\
\qquad \mathrm{d}+\mathrm{m}\end{array}$} & \multicolumn{2}{|c|}{$\begin{array}{c}\text { Whole sample } \\
\mathrm{d}+\mathrm{m}+\mathrm{w}+\mathrm{s}\end{array}$} & \multicolumn{2}{|c|}{$\begin{array}{l}\text { Divorced \& married } \\
\qquad \mathrm{d}+\mathrm{m}\end{array}$} & \multicolumn{2}{|c|}{$\begin{array}{l}\text { Whole sample } \\
\mathrm{d}+\mathrm{m}+\mathrm{w}+\mathrm{s}\end{array}$} & \multicolumn{2}{|c|}{$\begin{array}{c}\text { Divorced \& married } \\
\qquad \mathrm{d}+\mathrm{m}\end{array}$} \\
\hline & (1) & (2) & (3) & (4) & (5) & (6) & (7) & (8) & (9) & (10) & (11) & (12) \\
\hline Post*Treated & $\begin{array}{c}0.0394^{* * *} \\
(0.0125)\end{array}$ & $\begin{array}{c}0.0395^{* * *} \\
(0.0126)\end{array}$ & $\begin{array}{c}0.0193 \\
(0.0136)\end{array}$ & $\begin{array}{c}0.0196 \\
(0.0136)\end{array}$ & $\begin{array}{l}-0.0183 \\
(0.0131)\end{array}$ & $\begin{array}{l}-0.0186 \\
(0.0132)\end{array}$ & $\begin{array}{l}-0.00174 \\
(0.0165)\end{array}$ & $\begin{array}{l}-0.00218 \\
(0.0163)\end{array}$ & $\begin{array}{l}-6.972 \\
(6.831)\end{array}$ & $\begin{array}{l}-6.660 \\
(6.769)\end{array}$ & $\begin{array}{l}-15.93 \\
(10.16)\end{array}$ & $\begin{array}{l}-15.51 \\
(9.937)\end{array}$ \\
\hline Including Covariates & & $\mathrm{x}$ & & $\mathrm{x}$ & & $\mathrm{x}$ & & $\mathrm{x}$ & & $\mathrm{x}$ & & $\mathrm{x}$ \\
\hline Obs. in treatment group & 14,647 & 14,647 & 9,195 & 9,195 & 14,647 & 14,647 & 9,190 & 9,190 & 14,647 & 14,647 & 9,190 & 9,190 \\
\hline \multirow[t]{4}{*}{ Obs. in control group } & 19,451 & 19,451 & 15,169 & 15,169 & 19,442 & 19,442 & 15,165 & 15,165 & 19,442 & 19,442 & 15,165 & 15,165 \\
\hline & \multicolumn{4}{|c|}{$\begin{array}{r}\text { Probability of being } \\
\text { divorced/separated }\end{array}$} & \multicolumn{4}{|c|}{$\begin{array}{l}\text { Probability of being } \\
\text { the head of the household }\end{array}$} & & & & \\
\hline & \multicolumn{2}{|c|}{$\begin{array}{l}\text { Whole sample } \\
\mathrm{d}+\mathrm{m}+\mathrm{w}+\mathrm{s}\end{array}$} & \multicolumn{2}{|c|}{$\begin{array}{l}\text { Divorced \& married } \\
\qquad \mathrm{d}+\mathrm{m}\end{array}$} & \multicolumn{2}{|c|}{$\begin{array}{l}\text { Whole sample } \\
\mathrm{d}+\mathrm{m}+\mathrm{w}+\mathrm{s}\end{array}$} & \multicolumn{2}{|c|}{$\begin{array}{l}\text { Divorced \& married } \\
\qquad \mathrm{d}+\mathrm{m}\end{array}$} & & & & \\
\hline & (13) & (14) & (15) & (16) & (17) & (18) & (19) & (20) & & & & \\
\hline Post*Treated & $\begin{array}{l}-0.00966 \\
(0.0105)\end{array}$ & $\begin{array}{r}-0.00961 \\
(0.0104)\end{array}$ & $\begin{array}{l}-0.0109 \\
(0.0148)\end{array}$ & $\begin{array}{l}-0.0108 \\
(0.0146)\end{array}$ & $\begin{array}{l}0.00297 \\
(0.0146)\end{array}$ & $\begin{array}{l}0.00305 \\
(0.0145)\end{array}$ & $\begin{array}{r}-0.00882 \\
(0.0153)\end{array}$ & $\begin{array}{l}-0.00872 \\
(0.0152)\end{array}$ & & & & \\
\hline Including Covariates & & $\mathrm{x}$ & & $\mathrm{x}$ & & $\mathrm{x}$ & & $\mathrm{x}$ & & & & \\
\hline Obs. in treatment group & 14,647 & 14,647 & 9,195 & 9,195 & 14,647 & 14,647 & 9,195 & 9,195 & & & & \\
\hline Obs. in control group & 19,451 & 19,451 & 15,169 & 15,169 & 19,451 & 19,451 & 15,169 & 15,169 & & & & \\
\hline
\end{tabular}

The dependent variables are: a dummy that equals one when the wife receives a pension (columns 1-2), a dummy that equals one when she has no personal income (columns $3-4)$, the wife's monthly personal income in international 2009 PPP dollars (columns 5-6), the share of the wife's income within the household (columns 7-8) and within the couple (columns 9-10), and a a dummy that equals one if the wife is the head of the household (Columns 11-12). The coefficient on Post*Treated is the estimated parameter $\beta$ of equation 1 for the placebo DD estimates (OLS) specified in Section 4 (see Table 3). Period 1996-1998 is the placebo pre-treatment period and period 1999-2001 is the placebo post-treatment period. The placebo treatment group includes all women born between 1933 and 1936, and the placebo control group women born between 1942 and 1945. All regressions include the following control variables: cohort, year and quarter fixed effects, interactions between the last two, and a dummy that indicates whether the woman belongs to the top $1 \%$ of personal income. Other individual characteristics in the even columns are: a dummy variable that equals one if the maximum level of education attained is at least a high school diploma and regions fixed effects (29 urban areas). All results come from regressions using as sample weights the variable pondera in the EPH. The whole sample includes all women regardless of their marital status. The sample "divorced \& married" is restricted to married (m) and divorced/separated women (d), i.e. it excludes singles (s) and widows (w). Data source: Argentine Permanent Household Survey (Encuesta Permanente de Hogares Puntual, EPH). Robust standard errors clustered at cohort-year-quarter in parentheses. ${ }^{* * *} \mathrm{p}<0.01,{ }^{* *} \mathrm{p}<0.05,{ }^{*} \mathrm{p}<0.1$. 
Table 11: Placebo using pre-treatment data (1996-2001). Married women.

\begin{tabular}{|c|c|c|c|c|c|c|c|c|c|c|c|c|}
\hline & \multicolumn{2}{|c|}{$\begin{array}{c}\text { Wife receives } \\
\text { a pension }\end{array}$} & \multicolumn{2}{|c|}{$\begin{array}{c}\text { Wife does not have } \\
\text { personal income }\end{array}$} & \multicolumn{2}{|c|}{$\begin{array}{l}\text { Wife's personal } \\
\text { income }\end{array}$} & \multicolumn{2}{|c|}{$\begin{array}{c}\text { Wife's share of } \\
\text { income within couple }\end{array}$} & \multicolumn{2}{|c|}{$\begin{array}{c}\text { Wife's share of income } \\
\text { within household }\end{array}$} & \multicolumn{2}{|c|}{$\begin{array}{l}\text { Wife is the head } \\
\text { of household }\end{array}$} \\
\hline & $(1)$ & $(2)$ & $(3)$ & $(4)$ & $(5)$ & (6) & (7) & $(8)$ & (9) & $(10)$ & (11) & $(12)$ \\
\hline Post*Treated & $\begin{array}{r}0.0284^{* *} \\
(0.0142)\end{array}$ & $\begin{array}{l}0.0303^{* *} \\
(0.0141)\end{array}$ & $\begin{array}{l}-0.00232 \\
(0.0170)\end{array}$ & $\begin{array}{l}-0.00498 \\
(0.0171)\end{array}$ & $\begin{array}{l}-12.99 \\
(9.573)\end{array}$ & $\begin{array}{l}-10.68 \\
(9.703)\end{array}$ & $\begin{array}{c}-0.000107 \\
(0.0102)\end{array}$ & $\begin{array}{l}-0.000341 \\
(0.00994)\end{array}$ & $\begin{array}{l}-0.0192 \\
(0.0122)\end{array}$ & $\begin{array}{l}-0.0181 \\
(0.0120)\end{array}$ & $\begin{array}{l}-0.0138^{* *} \\
(0.00619)\end{array}$ & $\begin{array}{l}-0.0138^{* *} \\
(0.00629)\end{array}$ \\
\hline Education high (dummy) & & $\mathrm{x}$ & & $\mathrm{x}$ & & $\mathrm{x}$ & & $\mathrm{x}$ & & $\mathrm{x}$ & & $\mathrm{x}$ \\
\hline Region fixed effects & & $\mathrm{x}$ & & $\mathrm{x}$ & & $\mathrm{x}$ & & $\mathrm{x}$ & & $\mathrm{x}$ & & $\mathrm{x}$ \\
\hline Couple's age difference & & $\mathrm{x}$ & & $\mathrm{x}$ & & $\mathrm{x}$ & & $\mathrm{x}$ & & $\mathrm{x}$ & & $\mathrm{x}$ \\
\hline Couple's education difference & & $\mathrm{x}$ & & $\mathrm{x}$ & & $\mathrm{x}$ & & $\mathrm{x}$ & & $\mathrm{x}$ & & $\mathrm{x}$ \\
\hline Observations & 20,677 & 20,677 & 20,677 & 20,677 & 20,677 & 20,677 & 18,220 & 18,220 & 18,913 & 18,913 & 20,685 & 20,685 \\
\hline Obs. in treatment group & 7,942 & 7,942 & 7,942 & 7,942 & 7,942 & 7,942 & 7,135 & 7,135 & 7,375 & 7,375 & 7,946 & 7,946 \\
\hline Obs. in control group & 12,735 & 12,735 & 12,735 & 12,735 & 12,735 & 12,735 & 11,085 & 11,085 & 11,538 & 11,538 & 12,739 & 12,739 \\
\hline
\end{tabular}

wife's monthly personal income in international 2009 PPP dollars (columns 5-6), the share of the wife's income within the household (columns 7-8) and within the couple (9-10), and

a a dummy that equals one if the wife is the head of the household (Columns 11-12). The coefficient on Post*Treated is the estimated parameter $\beta$ of equation 1 for the placebo DD estimates (OLS) specified in Section 4 (see Table 3). Period 1996-1998 is the placebo pre-treatment period and period 1999-2001 is the placebo post-treatment period. The placebo treatment group includes all women born between 1933 and 1936, and the placebo control group women born between 1942 and 1945. All regressions include the following control variables: cohort, year and quarter fixed effects, interactions between the last two, and a dummy that indicates whether the woman belongs to the top $1 \%$ of personal income. Other individual characteristics in the even columns are: a dummy variable that equals one if the maximum level of education attained is at least a high school diploma; regions fixed effects (29 urban areas); and differences between spouses' age and level of education attained. All results come from regressions using as sample weights the variable pondera in the EPH. Data source: Argentine Permanent Household Survey prior to 2003 (Encuesta Permanente de Hogares Puntual). Robust standard errors clustered at cohort-year-quarter in parentheses. $* * * \mathrm{p}<0.01,{ }^{* *} \mathrm{p}<0.05, * \mathrm{p}<0.1$. 
Table 12: Means, by education

\begin{tabular}{|c|c|c|c|c|c|c|c|c|}
\hline \multirow[b]{3}{*}{ Variable } & \multicolumn{4}{|c|}{ Low educated } & \multicolumn{4}{|c|}{ High educated } \\
\hline & \multicolumn{2}{|c|}{ Control cohorts } & \multicolumn{2}{|c|}{ Treated cohorts } & \multicolumn{2}{|c|}{ Control cohorts } & \multicolumn{2}{|c|}{ Treated cohorts } \\
\hline & 2004-06 & 2007-09 & 2004-06 & 2007-09 & 2004-06 & 2007-09 & 2004-06 & 2007-09 \\
\hline \multicolumn{9}{|c|}{ All women } \\
\hline Pension recipient & 0.09 & 0.12 & 0.26 & 0.78 & 0.08 & 0.12 & 0.39 & 0.74 \\
\hline No personal income & 0.41 & 0.39 & 0.45 & 0.13 & 0.31 & 0.28 & 0.30 & 0.09 \\
\hline Personal income (Argentine Pesos: $\mathrm{AR} \$$ ) & 259 & 534 & 246.64 & 654.81 & 823.73 & 1592.84 & 758.58 & 1476.51 \\
\hline Personal income (2009 PPP USD) & 173 & 323 & 164.58 & 396.29 & 550.15 & 963.28 & 506.14 & 895.45 \\
\hline Divorced or separated & 0.14 & 0.13 & 0.09 & 0.09 & 0.18 & 0.17 & 0.12 & 0.14 \\
\hline Head of household & 0.32 & 0.37 & 0.37 & 0.42 & 0.32 & 0.35 & 0.39 & 0.49 \\
\hline Woman is the only responsible for housework & 0.39 & 0.42 & 0.44 & 0.45 & 0.34 & 0.36 & 0.44 & 0.45 \\
\hline Born abroad & 0.08 & 0.11 & 0.12 & 0.11 & 0.06 & 0.05 & 0.07 & 0.08 \\
\hline Live with partner & 0.12 & 0.11 & 0.07 & 0.08 & 0.07 & 0.07 & 0.05 & 0.06 \\
\hline Married & 0.56 & 0.55 & 0.51 & 0.49 & 0.61 & 0.59 & 0.55 & 0.45 \\
\hline Widow & 0.10 & 0.14 & 0.25 & 0.28 & 0.06 & 0.08 & 0.19 & 0.23 \\
\hline Single & 0.08 & 0.08 & 0.07 & 0.07 & 0.09 & 0.09 & 0.09 & 0.13 \\
\hline Active (in the labor market) & 0.55 & 0.50 & 0.33 & 0.21 & 0.68 & 0.63 & 0.44 & 0.31 \\
\hline Observations & 7,684 & 7,309 & 6,572 & 6,527 & 5,787 & 6,050 & 2,965 & 3,153 \\
\hline \multicolumn{9}{|c|}{ Divorced \& married } \\
\hline Pension recipient & 0.03 & 0.06 & 0.11 & 0.74 & 0.05 & 0.07 & 0.27 & 0.67 \\
\hline No personal income & 0.47 & 0.45 & 0.59 & 0.17 & 0.33 & 0.32 & 0.39 & 0.12 \\
\hline Personal income (Argentine Pesos: AR $\$$ ) & 224.20 & 461.44 & 165.81 & 546.38 & 785.54 & 1523.24 & 662.36 & 1263.80 \\
\hline Personal income (2009 PPP USD) & 149.96 & 279.77 & 110.81 & 330.47 & 525.01 & 921.34 & 442.51 & 765.28 \\
\hline Divorced or separated & 0.18 & 0.17 & 0.13 & 0.13 & 0.21 & 0.21 & 0.16 & 0.21 \\
\hline Head of household & 0.22 & 0.25 & 0.17 & 0.20 & 0.25 & 0.25 & 0.19 & 0.27 \\
\hline Woman is the only responsible for housework & 0.40 & 0.43 & 0.45 & 0.44 & 0.34 & 0.34 & 0.40 & 0.41 \\
\hline Born abroad & 0.08 & 0.12 & 0.12 & 0.12 & 0.06 & 0.06 & 0.07 & 0.09 \\
\hline Active (in the labor market) & 0.52 & 0.48 & 0.30 & 0.18 & 0.66 & 0.63 & 0.42 & 0.30 \\
\hline Observations & 1,029 & 996 & 574 & 544 & 966 & 970 & 354 & 387 \\
\hline \multicolumn{9}{|c|}{ Married } \\
\hline Pension recipient & 0.03 & 0.05 & 0.11 & 0.74 & 0.05 & 0.07 & 0.27 & 0.68 \\
\hline No personal income & 0.54 & 0.52 & 0.65 & 0.19 & 0.41 & 0.38 & 0.42 & 0.15 \\
\hline Personal income (Argentine Pesos: AR $\$$ ) & 190.51 & 406.01 & 141.91 & 510.42 & 687.10 & 1376.72 & 619.77 & 1193.79 \\
\hline Personal income (2009 PPP USD) & 127.32 & 245.94 & 94.73 & 308.98 & 459.56 & 833.43 & 413.78 & 721.48 \\
\hline Wife's share of income within household & 0.18 & 0.17 & 0.15 & 0.26 & 0.25 & 0.26 & 0.26 & 0.32 \\
\hline Wife's share of income within couple & 0.23 & 0.23 & 0.19 & 0.33 & 0.29 & 0.31 & 0.30 & 0.35 \\
\hline Head of household & 0.08 & 0.12 & 0.07 & 0.12 & 0.07 & 0.10 & 0.06 & 0.10 \\
\hline Wife is the only responsible for housework & 0.40 & 0.44 & 0.46 & 0.43 & 0.34 & 0.35 & 0.40 & 0.38 \\
\hline Husband does some housework & 0.22 & 0.26 & 0.28 & 0.35 & 0.27 & 0.28 & 0.33 & 0.35 \\
\hline Husband responsible for housework & 0.09 & 0.13 & 0.12 & 0.17 & 0.12 & 0.17 & 0.14 & 0.20 \\
\hline Have domestic service or external help & 0.01 & 0.01 & 0.01 & 0.02 & 0.09 & 0.10 & 0.08 & 0.07 \\
\hline Born abroad & 0.08 & 0.11 & 0.12 & 0.11 & 0.07 & 0.06 & 0.07 & 0.08 \\
\hline Couple's age difference & 2.63 & 2.28 & 2.46 & 2.56 & 2.67 & 2.78 & 2.57 & 2.35 \\
\hline Couple's education difference & -0.31 & -0.33 & -0.44 & -0.43 & 0.51 & 0.53 & 0.43 & 0.44 \\
\hline Active (in the labor market) & 0.46 & 0.43 & 0.26 & 0.15 & 0.60 & 0.58 & 0.38 & 0.25 \\
\hline Observations & 5,161 & 4,613 & 3,810 & 3,527 & 3,896 & 3,854 & 1,724 & 1,634 \\
\hline
\end{tabular}


Table 13: The effect of the reform on income By education

\begin{tabular}{|c|c|c|c|c|c|c|c|c|c|c|c|}
\hline & \multirow{2}{*}{\multicolumn{2}{|c|}{$\begin{array}{l}\text { Prob. receiving } \\
\text { a pension }\end{array}$}} & \multirow{2}{*}{\multicolumn{2}{|c|}{$\begin{array}{l}\text { Prob of no } \\
\text { income }\end{array}$}} & \multirow{2}{*}{\multicolumn{2}{|c|}{$\begin{array}{l}\text { Personal income } \\
\text { (USD } 2009 \text { PPP) }\end{array}$}} & \multicolumn{5}{|c|}{ Married Women } \\
\hline & & & & & & & \multirow{2}{*}{$\begin{array}{c}\text { Wife receives } \\
\text { a pension } \\
\text { (7) }\end{array}$} & \multirow{2}{*}{$\begin{array}{c}\text { Wife does not } \\
\text { have income } \\
\text { (8) }\end{array}$} & \multirow{2}{*}{$\begin{array}{c}\text { Wife's } \\
\text { income } \\
(9)\end{array}$} & \multirow{2}{*}{$\begin{array}{c}\text { Wife's share of income } \\
\text { within household } \\
\text { (10) }\end{array}$} & \multirow{2}{*}{$\begin{array}{c}\text { Wife's share of income } \\
\text { within couple } \\
\text { (11) }\end{array}$} \\
\hline & $\begin{array}{c}\mathrm{d}+\mathrm{m}+\mathrm{w}+\mathrm{s} \\
\text { (1) }\end{array}$ & $\begin{array}{c}\mathrm{d}+\mathrm{m} \\
(2)\end{array}$ & $\begin{array}{c}\mathrm{d}+\mathrm{m}+\mathrm{w}+\mathrm{s} \\
\text { (3) }\end{array}$ & $\begin{array}{c}\mathrm{d}+\mathrm{m} \\
(4)\end{array}$ & $\begin{array}{c}\mathrm{d}+\mathrm{m}+\mathrm{w}+\mathrm{s} \\
\text { (5) }\end{array}$ & $\begin{array}{c}\mathrm{d}+\mathrm{m} \\
(6)\end{array}$ & & & & & \\
\hline \multicolumn{12}{|l|}{ Education: Low } \\
\hline Post*treated & $\begin{array}{c}0.496^{* * *} \\
(0.0161)\end{array}$ & $\begin{array}{c}0.610^{* * *} \\
(0.0192)\end{array}$ & $\begin{array}{r}-0.302^{* * *} \\
(0.0161)\end{array}$ & $\begin{array}{c}-0.412^{* * *} \\
(0.0217)\end{array}$ & $\begin{array}{c}82.87^{* * *} \\
(9.833)\end{array}$ & $\begin{array}{c}92.04^{* * *} \\
(11.71)\end{array}$ & $\begin{array}{c}0.616^{* * *} \\
(0.0195)\end{array}$ & $\begin{array}{c}-0.450^{* * *} \\
(0.0232)\end{array}$ & $\begin{array}{c}101.9 * * * \\
(12.30)\end{array}$ & $\begin{array}{c}0.125^{* * *} \\
(0.0107)\end{array}$ & $\begin{array}{c}0.149^{* * *} \\
(0.0129)\end{array}$ \\
\hline \multicolumn{12}{|l|}{ Education: High } \\
\hline Post ${ }^{*}$ treated & $\begin{array}{c}0.305^{* * *} \\
(0.0160)\end{array}$ & $\begin{array}{l}0.375^{* * *} \\
(0.0226)\end{array}$ & $\begin{array}{c}-0.194^{* * *} \\
(0.0154)\end{array}$ & $\begin{array}{c}-0.260^{* * *} \\
(0.0188)\end{array}$ & $\begin{array}{c}75.57^{* * *} \\
(28.77)\end{array}$ & $\begin{array}{l}52.12^{*} \\
(29.01)\end{array}$ & $\begin{array}{c}0.391^{* * *} \\
(0.0239)\end{array}$ & $\begin{array}{c}-0.266^{* * *} \\
(0.0231)\end{array}$ & $\begin{array}{c}47.09 \\
(35.94)\end{array}$ & $\begin{array}{c}0.0583^{* * *} \\
(0.0133)\end{array}$ & $\begin{array}{c}0.0459^{* * *} \\
(0.0147)\end{array}$ \\
\hline Couple's age difference & & & & & & & $\mathrm{x}$ & $\mathrm{x}$ & $\mathrm{x}$ & $\mathrm{x}$ & $\mathrm{x}$ \\
\hline Couple's education difference & & & & & & & $\mathrm{x}$ & $\mathrm{x}$ & $\mathrm{x}$ & $\mathrm{x}$ & $\mathrm{x}$ \\
\hline Obs. in treatment group & 19,217 & 12,554 & 19,217 & 12,554 & 19,217 & 12,554 & 10,304 & 10,304 & 10,304 & 10,304 & 10,304 \\
\hline Obs. in control group & 26,830 & 21,485 & 26,830 & 21,485 & 26,830 & 21,485 & 16,853 & 16,853 & 16,853 & 16,853 & 16,853 \\
\hline Mean dep. var. (Low Edu) & 0.26 & 0.11 & 0.45 & 0.59 & 164.6 & 110.81 & 0.11 & 0.65 & 94.73 & 0.15 & 0.19 \\
\hline Mean dep. var. (High Edu) & 0.39 & 0.27 & 0.3 & 0.39 & 506.1 & 442.51 & 0.27 & 0.42 & 413.78 & 0.26 & 0.30 \\
\hline
\end{tabular}

The dependent variables are: a dummy that equals one when the woman receives a pension (columns 1-2 and 7), a dummy that equals one when she has no personal income (columns 3-4 and 8), and the woman's monthly personal income in dollars (PPP 2009) (columns 5-6 and 9). For the subsample of married women additional dependent variables are the share of the wife's income within the household (column 10) and within the couple (column 11). The coefficient on Post*Treated is the estimated parameter $\beta$ of equation 1 which is the DD estimates (OLS) of the effect of the reform on each of the outcomes, separating the samples by educational level—high and low, where low education indicates less than high school diploma. Period 2004-2006 is the pre-treatment period and period 2007-2009 is the post-treatment period. The treatment group includes all women born between 1941 and 1944 , and the control group women born between 1950 and 1953. All regressions include the following control variables: cohort, year and quarter fixed effects, interactions between the last two, and a dummy that indicates whether the woman belongs to the top $1 \%$ of personal income. Other individual characteristics are a dummy variable that equals one if the woman was born abroad and regions fixed effects $(29$ urban areas). Regressions in columns 7 to 11 also control for differences in age and education between spouses. All results come from regressions using as sample weights the variable pondera in the EPH. The whole sample includes all women regardless of their marital status. The sample of divorced (d) and married (m) is restricted to married and divorced/separated women, i.e. it excludes singles (s) and widows (w). Data source: Argentine Continuous Permanent Household Survey (Encuesta Permanente de Hogares Continua, EPH). Robust standard errors clustered at cohort-year-quarter in parentheses. ${ }^{* * *} \mathrm{p}<0.01,{ }^{* *} \mathrm{p}<0.05,{ }^{*} \mathrm{p}<0.1$. 
Table 14: Effects of the reform on the probability of being divorced/separated and the bargaining power of women By education

\begin{tabular}{|c|c|c|c|c|c|c|c|c|c|c|c|}
\hline & \multirow{2}{*}{\multicolumn{2}{|c|}{$\begin{array}{c}\text { Women is } \\
\text { divorced/separated }\end{array}$}} & \multirow{2}{*}{\multicolumn{2}{|c|}{$\begin{array}{l}\text { Women is the } \\
\text { head of the household }\end{array}$}} & \multirow{2}{*}{\multicolumn{2}{|c|}{$\begin{array}{l}\text { Woman is the only } \\
\text { responsible for housework }\end{array}$}} & \multicolumn{5}{|c|}{ Married women } \\
\hline & & & & & & & \multirow{3}{*}{$\begin{array}{c}\text { Wife is head } \\
\text { of household } \\
\text { (7) }\end{array}$} & \multirow{3}{*}{$\begin{array}{l}\text { Wife only responsible } \\
\text { for housework } \\
\text { (8) }\end{array}$} & \multirow{3}{*}{$\begin{array}{l}\text { Domestic service } \\
\text { or external help } \\
\text { (9) }\end{array}$} & \multirow{3}{*}{$\begin{array}{c}\text { Husband does } \\
\text { some or most housework } \\
\text { (10) }\end{array}$} & \multirow{3}{*}{$\begin{array}{c}\text { Husband does } \\
\text { most housework } \\
\text { (11) }\end{array}$} \\
\hline & $\mathrm{d}+\mathrm{m}+\mathrm{w}+\mathrm{s}$ & $d+m$ & $\mathrm{~d}+\mathrm{m}+\mathrm{w}+\mathrm{s}$ & $d+m$ & $d+m+w+s$ & $d+m$ & & & & & \\
\hline & (1) & (2) & (3) & (4) & (5) & (6) & & & & & \\
\hline \multicolumn{12}{|l|}{ Education: Low } \\
\hline \multirow[t]{2}{*}{ Post*treated } & 0.0114 & 0.0113 & 0.00303 & 0.00543 & -0.0188 & $-0.0443^{* *}$ & 0.0144 & $-0.0612^{* * *}$ & 0.0073 & 0.0306 & 0.0172 \\
\hline & $(0.0101)$ & $(0.0138)$ & $(0.0144)$ & $(0.0139)$ & $(0.0162)$ & $(0.0173)$ & $(0.0107)$ & $(0.0186)$ & $(0.0042)$ & $(0.0194)$ & $(0.0141)$ \\
\hline \multicolumn{12}{|l|}{ Education: High } \\
\hline \multirow[t]{2}{*}{ Post*treated } & $0.0312^{* *}$ & $0.0563^{* * *}$ & $0.0731^{* * *}$ & $0.0834^{* * *}$ & -0.00516 & 0.00495 & 0.0168 & -0.0388 & 0.0043 & 0.0079 & 0.0236 \\
\hline & $(0.0142)$ & $(0.0196)$ & $(0.0202)$ & $(0.0220)$ & $(0.0190)$ & $(0.0224)$ & $(0.0131)$ & $(0.0236)$ & $(0.0124)$ & $(0.0269)$ & $(0.0205)$ \\
\hline Observations & 46,047 & 34,039 & 46,047 & 34,039 & 46,047 & 34,039 & 27,157 & 27,157 & 27,157 & 27,157 & 27,157 \\
\hline Obs. in treatment group & 19,217 & 12,554 & 19,217 & 12,554 & 19,217 & 12,554 & 10,304 & 10,304 & 10,304 & 10,304 & 10,304 \\
\hline Obs in control group & 26,830 & 21,485 & 26,830 & 21,485 & 26,830 & 21,485 & 16,853 & 16,853 & 16,853 & 16,853 & 16,853 \\
\hline Mean dep. var. (Low Edu) & 0.09 & 0.13 & 0.37 & 0.17 & 0.44 & 0.45 & 0.07 & 0.46 & 0.01 & 0.28 & 0.12 \\
\hline Mean dep. var. (High Edu) & 0.12 & 0.16 & 0.39 & 0.19 & 0.44 & 0.4 & 0.06 & 0.4 & 0.08 & 0.33 & 0.14 \\
\hline
\end{tabular}

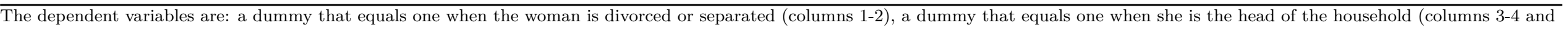

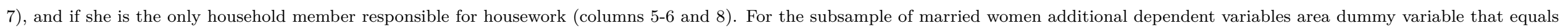

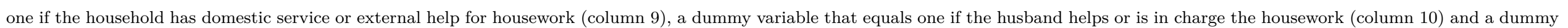

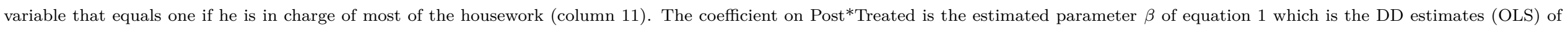

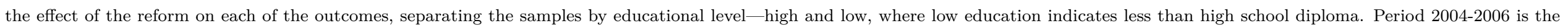

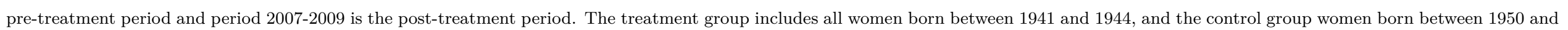

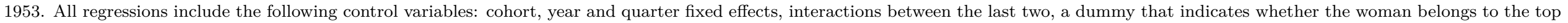

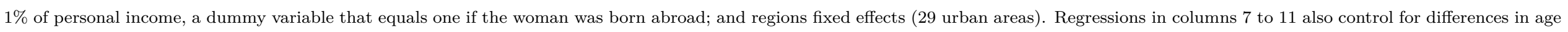

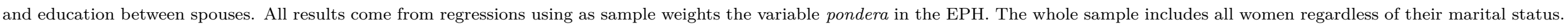

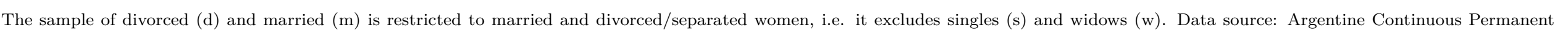
Household Survey (Encuesta Permanente de Hogares Continua, EPH). Robust standard errors clustered at cohort-year-quarter in parentheses. ${ }^{* * *} \mathrm{p}<0.01,{ }^{* *} \mathrm{p}<0.05,{ }^{*} \mathrm{p}<0.1$. 
Table 15: Panel data fixed effects estimates Sample of married women

\begin{tabular}{|c|c|c|c|c|c|c|c|c|c|}
\hline & $\begin{array}{c}\text { Pension } \\
\text { receipt } \\
\text { (1) }\end{array}$ & $\begin{array}{l}\text { No personal } \\
\text { Income } \\
(2)\end{array}$ & $\begin{array}{c}\text { Personal } \\
\text { Income } \\
\text { (USD PPP) } \\
(3)\end{array}$ & $\begin{array}{c}\text { Share of } \\
\text { Income Within } \\
\text { Couple } \\
(4)\end{array}$ & $\begin{array}{c}\text { Share of Income } \\
\text { Within } \\
\text { Household } \\
\text { (5) }\end{array}$ & $\begin{array}{l}\text { Prob. } \\
\text { Active } \\
\text { (6) }\end{array}$ & $\begin{array}{c}\text { Wife only } \\
\text { Responsible } \\
\text { for Housework } \\
\text { (7) }\end{array}$ & $\begin{array}{c}\text { Domestic } \\
\text { service or } \\
\text { external help } \\
\text { (8) }\end{array}$ & $\begin{array}{c}\text { Husband } \\
\text { does some } \\
\text { housework } \\
\text { (9) }\end{array}$ \\
\hline Post*treated & $\begin{array}{c}0.302^{* * *} \\
(0.0202)\end{array}$ & $\begin{array}{c}-0.242^{* * *} \\
(0.0215)\end{array}$ & $\begin{array}{c}40.02^{* * *} \\
(12.04)\end{array}$ & $\begin{array}{c}0.0804^{* * *} \\
(0.0093) \\
\end{array}$ & $\begin{array}{c}0.0628^{* * *} \\
(0.0089) \\
\end{array}$ & $\begin{array}{l}-0.0209^{*} \\
(0.0118)\end{array}$ & $\begin{array}{c}0.0006 \\
(0.0151) \\
\end{array}$ & $\begin{array}{l}-0.0014 \\
(0.0059) \\
\end{array}$ & $\begin{array}{c}0.0122 \\
(0.0173) \\
\end{array}$ \\
\hline $\begin{array}{l}\text { Education: Low } \\
\text { Post*treated }\end{array}$ & $\begin{array}{c}0.375^{* * *} \\
(0.0256)\end{array}$ & $\begin{array}{c}-0.312^{* * *} \\
(0.0279)\end{array}$ & $\begin{array}{c}72.24^{* * *} \\
(11.31)\end{array}$ & $\begin{array}{c}0.104^{* * *} \\
(0.0120)\end{array}$ & $\begin{array}{c}0.0791^{* * *} \\
(0.0107)\end{array}$ & $\begin{array}{l}-0.0278^{*} \\
(0.0160)\end{array}$ & $\begin{array}{l}-0.0162 \\
(0.0207)\end{array}$ & $\begin{array}{c}0.0067 \\
(0.0050)\end{array}$ & $\begin{array}{c}0.0180 \\
(0.0201)\end{array}$ \\
\hline $\begin{array}{l}\text { Education: High } \\
\text { Post*treated }\end{array}$ & $\begin{array}{c}0.152^{* * *} \\
(0.0250)\end{array}$ & $\begin{array}{c}-0.103^{* * *} \\
(0.0233)\end{array}$ & $\begin{array}{l}-10.94 \\
(23.72)\end{array}$ & $\begin{array}{c}0.0295^{* *} \\
(0.0122)\end{array}$ & $\begin{array}{c}0.0280^{* *} \\
(0.0120)\end{array}$ & $\begin{array}{l}-0.0118 \\
(0.0146)\end{array}$ & $\begin{array}{c}0.0294 \\
(0.0270)\end{array}$ & $\begin{array}{l}-0.0110 \\
(0.0146)\end{array}$ & $\begin{array}{l}-0.0021 \\
(0.0315)\end{array}$ \\
\hline Observations & 7,481 & 7,481 & 7,481 & 7,197 & 7,352 & 7,476 & 7,481 & 7,481 & 7,364 \\
\hline Individuals & 2,364 & 2,364 & 2,364 & 2,322 & 2,338 & 2,364 & 2,364 & 2,364 & 2,336 \\
\hline Obs. in treatment group & 2728 & 2728 & 2728 & 2728 & 2728 & 2728 & 2728 & 2728 & 2728 \\
\hline Obs. in control group & 4753 & 4753 & 4753 & 4753 & 4753 & 4753 & 4753 & 4753 & 4753 \\
\hline
\end{tabular}

The dependent variables are: a dummy that equals one when the wife receives a pension (column 1), a dummy that equals one when she has no personal income (column 2), wife's monthly personal income in USD 2009 PPP dollars (column 3), the share of wife's income within the household (column 4) and within the couple (column 5), a dummy that equals one if the wife is economically active (column 6), a dummy that equals one if she is the only household member responsible for housework (column 7 ), a dummy variable that equals one if the household has domestic service or external help for housework (columns 8 ), and a dummy variable that equals one if the husband helps or is in charge of most of the housework (columns 9). The coefficient on Post*Treated is the estimated parameter $\beta$ of equation 1 -with an additional unobserved time-invariant individual effect - which is the DD estimates of the effect of the reform on each of the outcomes. Period 2005-IV-2006-IV is the pre-treatment period and period 2007-I-2008-I is the post-treatment period. The treatment group includes all women born between 1941 and 1945, and the control group women born between 1948 and 1953. All regressions include the following control variables: year and quarter fixed effects, interactions between the last two, and a dummy that indicates whether the woman belongs to the top $1 \%$ of personal income. Data source: Argentine Continuous Permanent Household Survey (Encuesta Permanente de Hogares Continua, EPH). Robust standard errors clustered at cohort-year-quarter in parentheses. ${ }^{* * *} \mathrm{p}<0.01,{ }^{* *} \mathrm{p}<0.05,{ }^{*} \mathrm{p}<0.1$. 
Table 16: Placebo panel data fixed effects estimates

\begin{tabular}{|c|c|c|c|c|c|c|c|c|c|}
\hline \multicolumn{10}{|c|}{ Sample of married women } \\
\hline & $\begin{array}{l}\text { Pension } \\
\text { receipt } \\
\text { (1) }\end{array}$ & $\begin{array}{l}\text { No personal } \\
\text { Income } \\
\\
(2)\end{array}$ & $\begin{array}{c}\text { Personal } \\
\text { Income } \\
\text { (USD PPP) } \\
\quad(3)\end{array}$ & $\begin{array}{c}\text { Share of } \\
\text { Income Within } \\
\text { Couple } \\
(4)\end{array}$ & $\begin{array}{c}\text { Share of Income } \\
\text { Within } \\
\text { Household } \\
\text { (5) }\end{array}$ & $\begin{array}{l}\text { Prob. } \\
\text { active } \\
(6)\end{array}$ & $\begin{array}{c}\text { Wife only } \\
\text { Responsible } \\
\text { for Housework } \\
\text { (7) }\end{array}$ & $\begin{array}{c}\text { Domestic } \\
\text { service or } \\
\text { external help } \\
\text { (8) }\end{array}$ & $\begin{array}{c}\text { Husband } \\
\text { does some } \\
\text { housework } \\
\text { (9) }\end{array}$ \\
\hline Post*treated & $\begin{array}{c}0.00225 \\
(0.00610)\end{array}$ & $\begin{array}{l}0.00734 \\
(0.0108)\end{array}$ & $\begin{array}{c}-26.64^{* * *} \\
(8.311)\end{array}$ & $\begin{array}{l}-0.00875 \\
(0.00803)\end{array}$ & $\begin{array}{l}-0.00420 \\
(0.00743)\end{array}$ & $\begin{array}{l}-0.0202^{*} \\
(0.0110)\end{array}$ & $\begin{array}{l}0.00873 \\
(0.0198)\end{array}$ & $\begin{array}{c}0.00817 \\
(0.00686)\end{array}$ & $\begin{array}{l}0.00119 \\
(0.0176)\end{array}$ \\
\hline $\begin{array}{l}\text { Education: Low } \\
\text { Post*treated }\end{array}$ & $\begin{array}{l}-0.000485 \\
(0.00801)\end{array}$ & $\begin{array}{l}-0.00208 \\
(0.0157)\end{array}$ & $\begin{array}{l}-10.74 \\
(7.438)\end{array}$ & $\begin{array}{l}-0.00583 \\
(0.00985)\end{array}$ & $\begin{array}{l}-0.00478 \\
(0.00908)\end{array}$ & $\begin{array}{l}-0.00712 \\
(0.0143)\end{array}$ & $\begin{array}{l}-0.0157 \\
(0.0227)\end{array}$ & $\begin{array}{c}0.00334 \\
(0.00537)\end{array}$ & $\begin{array}{l}0.00393 \\
(0.0213)\end{array}$ \\
\hline $\begin{array}{l}\text { Education: High } \\
\text { Post*treated }\end{array}$ & $\begin{array}{c}0.0118 \\
(0.0111)\end{array}$ & $\begin{array}{c}0.0233 \\
(0.0169)\end{array}$ & $\begin{array}{c}-54.61^{* * *} \\
(18.68)\end{array}$ & $\begin{array}{l}-0.0124 \\
(0.0135)\end{array}$ & $\begin{array}{l}-0.00205 \\
(0.0124)\end{array}$ & $\begin{array}{c}-0.0475^{* *} \\
(0.0192)\end{array}$ & $\begin{array}{c}0.0582 \\
(0.0374)\end{array}$ & $\begin{array}{c}0.0147 \\
(0.0173)\end{array}$ & $\begin{array}{l}-0.00208 \\
(0.0323)\end{array}$ \\
\hline Observations & 8,160 & 8.160 & 8,160 & 7,630 & 7,908 & 8,155 & 8,160 & 8,160 & 7,988 \\
\hline Individuals & 2,534 & 2,534 & 2,534 & 2,460 & 2,493 & 2,534 & 2,534 & 2,534 & 2,493 \\
\hline Obs. in treatment group & 2946 & 2946 & 2946 & 2946 & 2946 & 2946 & 2946 & 2946 & 2946 \\
\hline Obs. in control group & 5214 & 5214 & 5214 & 5214 & 5214 & 5214 & 5214 & 5214 & 5214 \\
\hline
\end{tabular}

The dependent variables are: a dummy that equals one when the wife receives a pension (column 1), a dummy that equals one when she has no personal income (column

2), wife's monthly personal income in USD 2009 PPP dollars (column 3), the share of wife's income within the household (column 4) and within the couple (column 5), a dummy that equals one if the wife is economically active (column 6), a dummy that equals one if she is the only household member responsible for housework (column 7), a dummy variable that equals one if the household has domestic service or external help for housework (columns 8 ), and a dummy variable that equals one if the husband helps or is in charge of most of the housework (columns 9). The coefficient on Post*Treated is the estimated parameter $\beta$ of equation 1 - with an additional unobserved time-invariant individual effect - for the placebo DD estimate on each of the outcomes. Period 2003-IV-2004-IV is the placebo pre-treatment period and period 2005-I-2006-I is the placebo post-treatment period. The placebo treatment group includes all women born between 1939 and 1943 , and the control group women born between 1946 and 1951. All regressions include the following control variables: year and quarter fixed effects, interactions between the last two, and a dummy that indicates whether the woman belongs to the top $1 \%$ of personal income. Data source: Argentine Continuous Permanent Household Survey (Encuesta Permanente de Hogares Continua, EPH). Robust standard errors clustered at cohort-year-quarter in parentheses. ${ }^{* * *} \mathrm{p}<0.01,{ }^{* *} \mathrm{p}<0.05, * \mathrm{p}<0.1$. 
Figure 1: Percentage of individuals with personal income $=0$
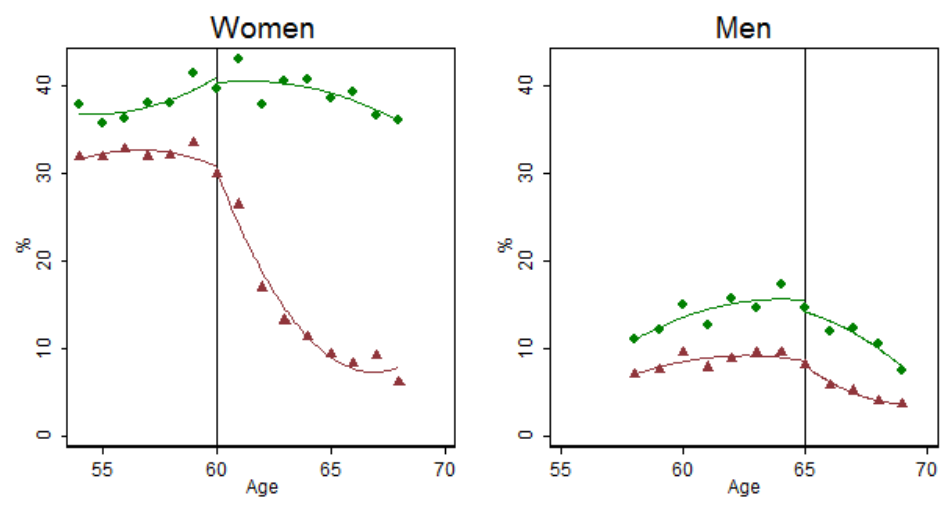

- Pre-reform

4 Post-reform

Source: Argentine Continuous Permanent Household Survey (EPH)

Figure 2: Pension recipients (as \% of age-eligible individuals)
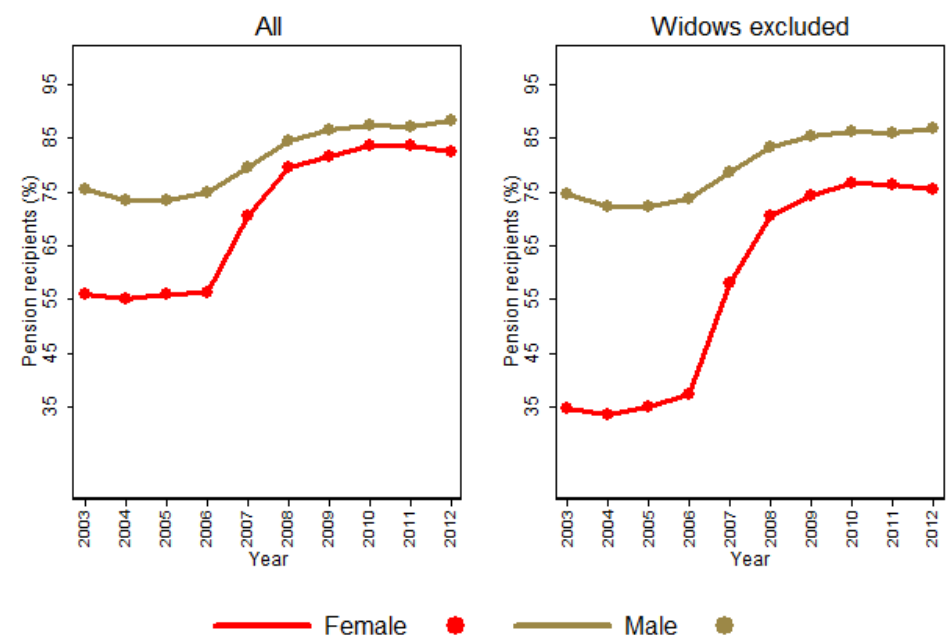

Source: Argentine Continuous Permanent Household Survey (EPH) 
Figure 3: News related to the moratorium

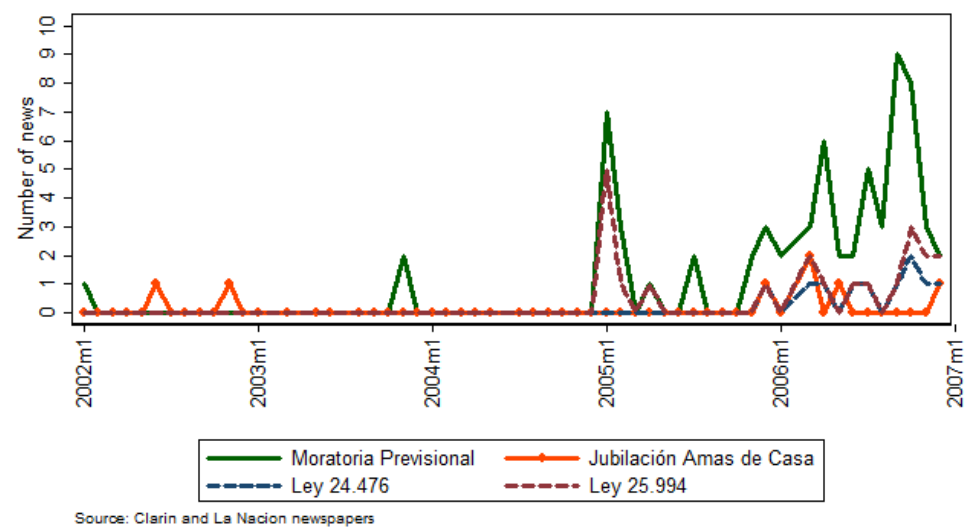

Figure 4: Google searches related to the moratorium

Trends Web Search Interest: "ley 24476", "Jubilacion ama de casa"+"jubilacion amas de casa", "moratoria previsional". Argentina, 2004 - present. इस

Search terms

$\times$ "ley 24476"

$\times$ "jubilacion ama

× "moratoria pres

+ Add term

- Other comparisons

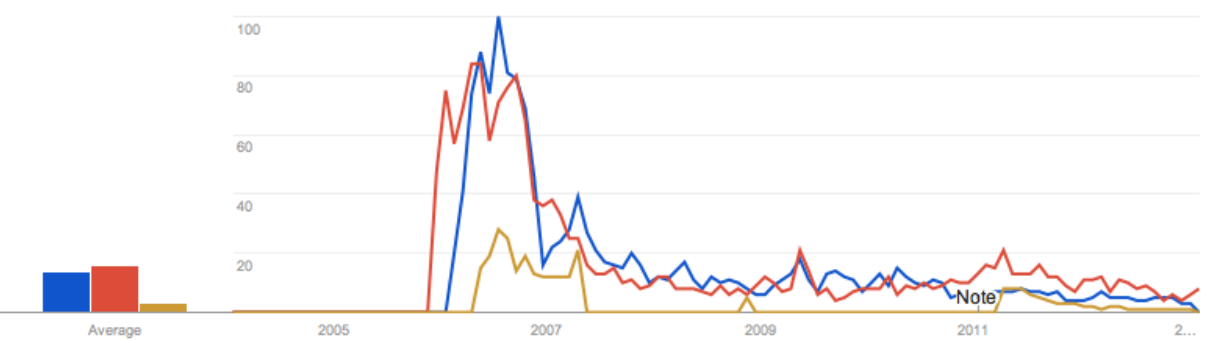


Figure 5: Evolution of the proportion of pension recipients by cohort
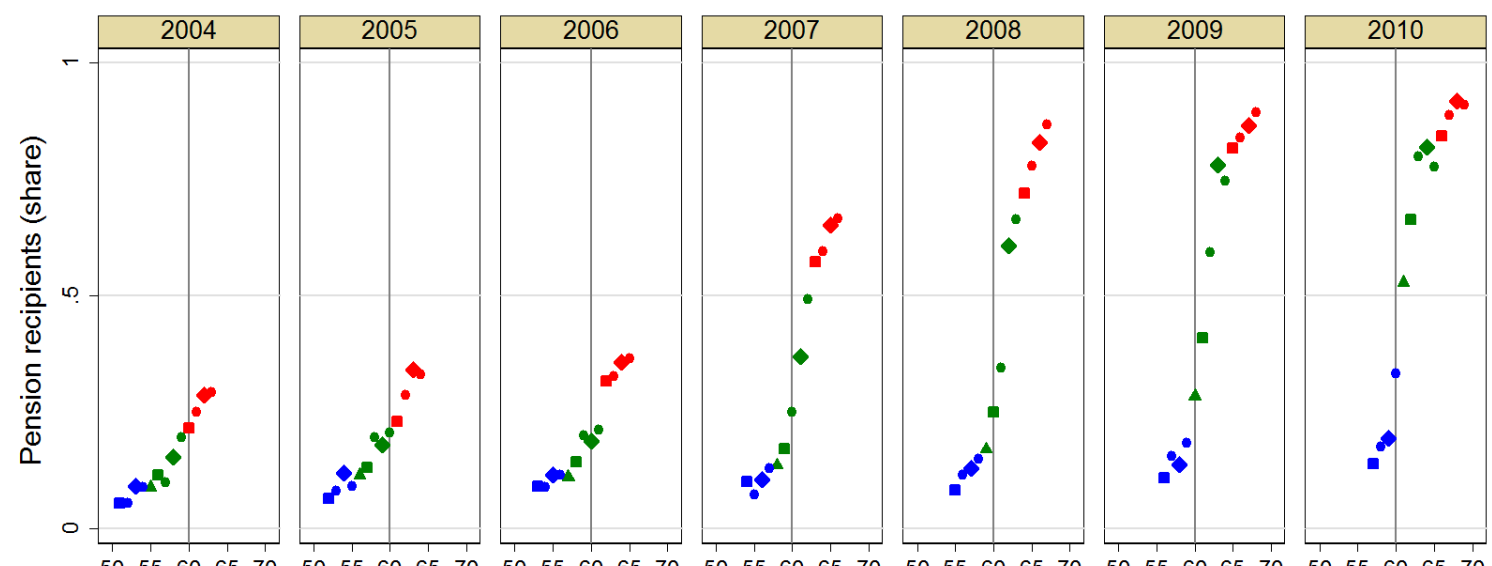

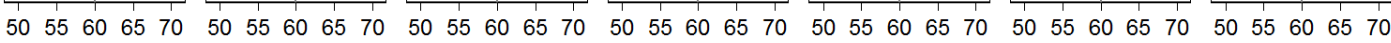
Age

- $1941 \bullet 1942 \bullet 1943$

- $1944 \cdot 1945 \diamond 1946$

- 1947

- $1948 \triangle 1949 \bullet 1950$

- $1951 \bullet 1952$ - 1953

Source: Argentine Continuous Permanent Household Survey (EPH) 
Figure 6:

Pension recipients

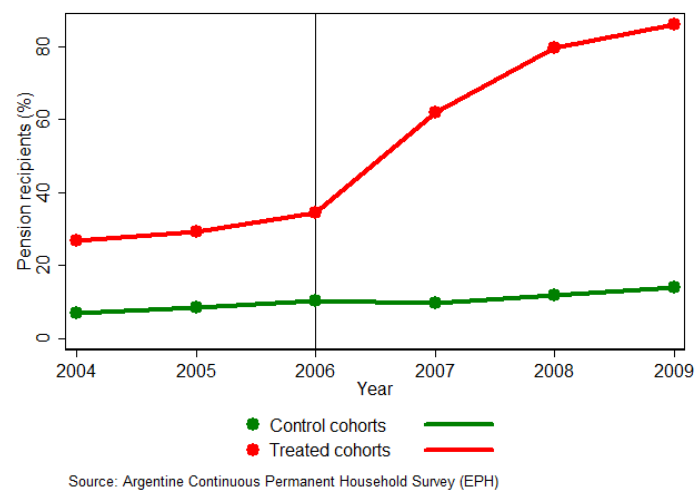

Figure 8:

Wife's share of income within the couple

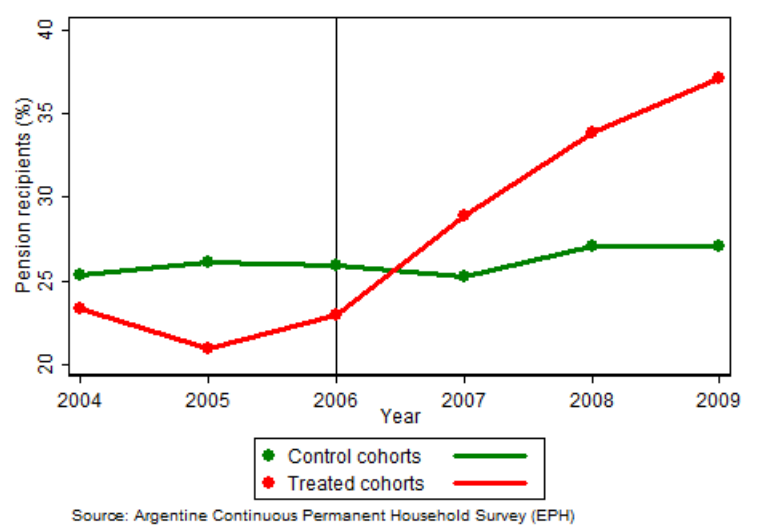

Figure 7:

Women without personal income

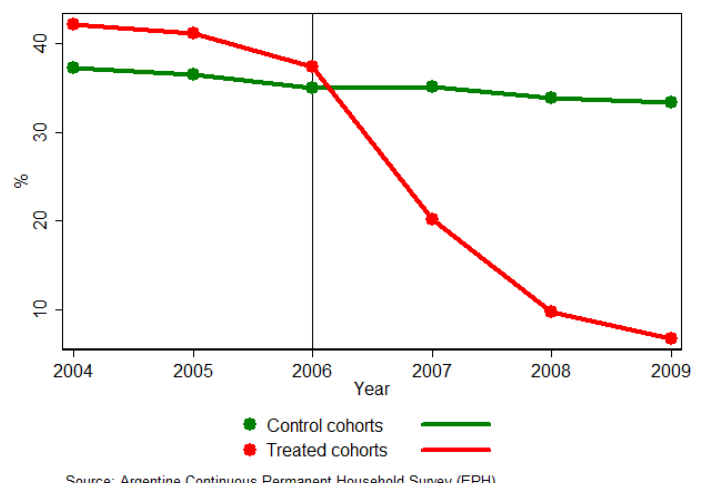

Figure 9:

Wife's share of income within household

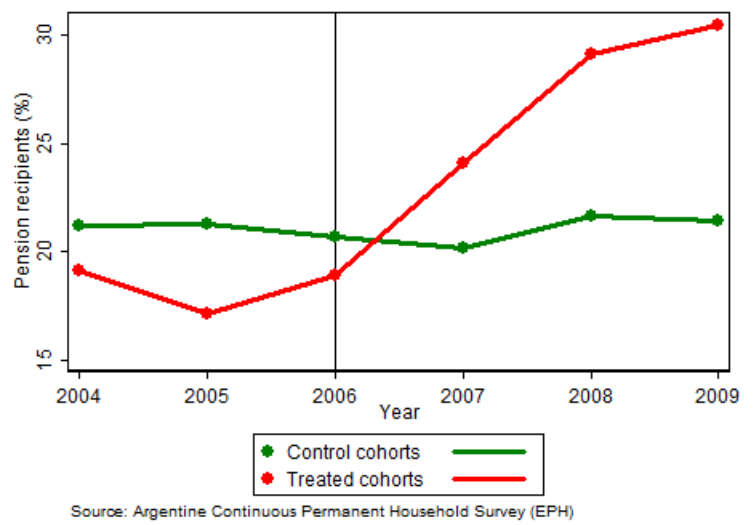

Figure 10:

Evolution of monthly personal income

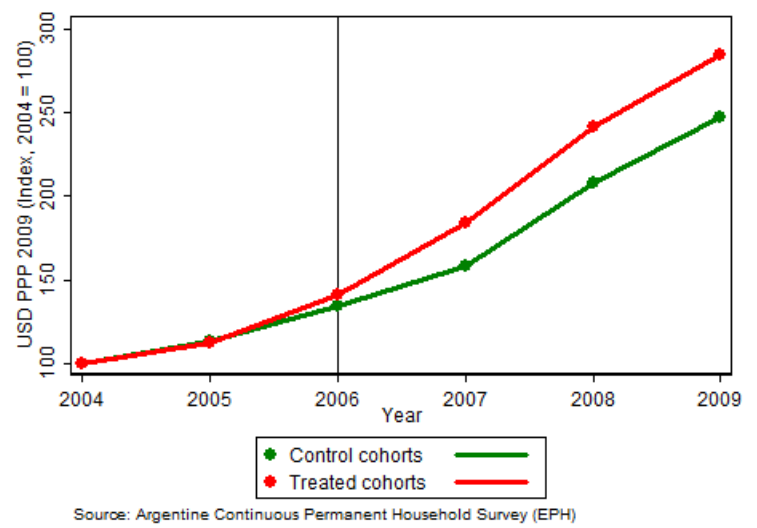


Figure 11:

Women is divorced/separated

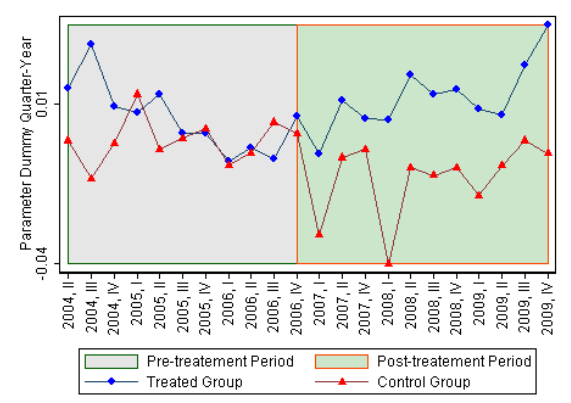

Figure 14:

Women is the head of the household Sample of married women

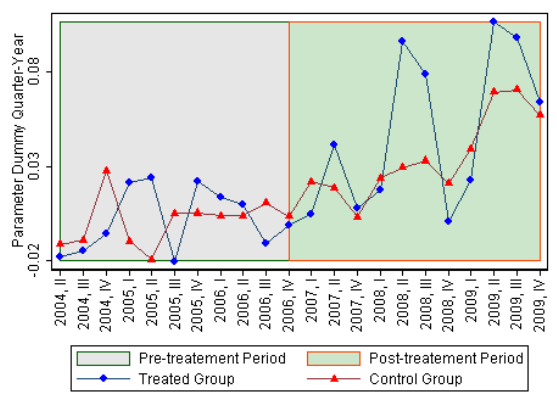

Figure 12:

Women is the head of household Women is the only responsible for

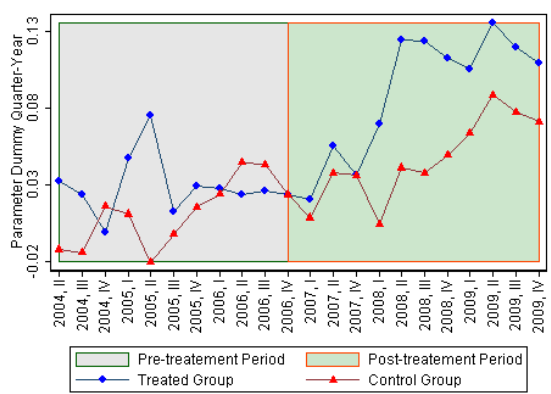

Figure 13:

housework

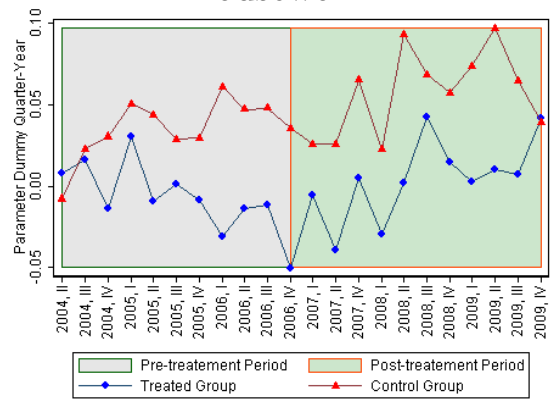

Figure 15:

Women is the only responsible for housework Sample of married women

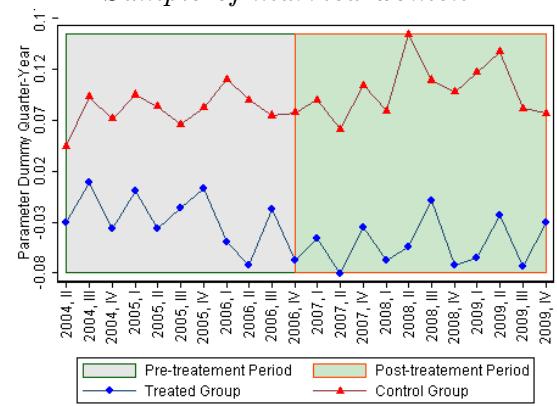

In these figures we plot the estimated parameters $\delta_{t, g}$ of the following equation, which was run separately for individuals in the control and in the treated group,

$$
y_{i, g, t}=\alpha_{g}+\delta_{t, g}+\delta_{i, g}^{C}+X_{i}^{\prime} \gamma_{g}+\varepsilon_{i, t} \quad, \quad g=\{\text { treated, control }\}
$$

where $y_{i, g, t}$ is the outcome of interest for individual i, of group g (control or treated), in period t; $\delta_{t, g}$ are quarter-year fixed effects; $\delta_{i, g}^{C}$ are cohort fixed effects; $X_{i, g}$ is a vector of individual characteristics (education, born abroad and region fixed effects); and $\varepsilon_{i, t}$ is a residual. 